\title{
Article \\ GSH and Zinc Supplementation Attenuate Cadmium-Induced Cellular Stress and Stimulation of Choline Uptake in Cultured Neonatal Rat Choroid Plexus Epithelia
}

\author{
Samantha D. Francis Stuart ${ }^{1,2}$ and Alice R. Villalobos $1,2, *$ (D) \\ 1 Department of Nutrition and Food Science, Texas A\&M University, College Station, TX 77843, USA; \\ sdfstuart@gmail.com \\ 2 Department of Veterinary Integrative Biosciences, Texas A\&M University, College Station, TX 77843, USA \\ * Correspondence: alice.villalobos@ttuhsc.edu; Tel.: +1-806-743-2057
}

check for

updates

Citation: Francis Stuart, S.D.; Villalobos, A.R. GSH and Zinc Supplementation Attenuate

Cadmium-Induced Cellular Stress and Stimulation of Choline Uptake in Cultured Neonatal Rat Choroid Plexus Epithelia. Int. J. Mol. Sci. 2021, 22, 8857. https://doi.org/10.3390/ ijms22168857

Academic Editor: Louise C. Abbott

Received: 26 June 2021

Accepted: 11 August 2021

Published: 17 August 2021

Publisher's Note: MDPI stays neutral with regard to jurisdictional claims in published maps and institutional affiliations.

Copyright: (c) 2021 by the authors. Licensee MDPI, Basel, Switzerland. This article is an open access article distributed under the terms and conditions of the Creative Commons Attribution (CC BY) license (https:// creativecommons.org/licenses/by/ $4.0 /)$

\begin{abstract}
Choroid plexus (CP) sequesters cadmium and other metals, protecting the brain from these neurotoxins. These metals can induce cellular stress and modulate homeostatic functions of $\mathrm{CP}$, such as solute transport. We previously showed in primary cultured neonatal rat $\mathrm{CP}$ epithelial cells (CPECs) that cadmium induced cellular stress and stimulated choline uptake at the apical membrane, which interfaces with cerebrospinal fluid in situ. Here, in CPECs, we characterized the roles of glutathione (GSH) and Zinc supplementation in the adaptive stress response to cadmium. Cadmium increased GSH and decreased the reduced GSH-to-oxidized GSH (GSSG) ratio. Heat shock protein-70 (Hsp70), heme oxygenase (HO-1), and metallothionein (Mt-1) were induced along with the catalytic and modifier subunits of glutamate cysteine ligase (GCL), the rate-limiting enzyme in GSH synthesis. Inhibition of GCL by L-buthionine sulfoximine (BSO) enhanced stress protein induction and stimulation of choline uptake by cadmium. Zinc alone did not induce Hsp70, HO-1, or GCL subunits, or modulate choline uptake. Zinc supplementation during cadmium exposure attenuated stress protein induction and stimulation of choline uptake; this effect persisted despite inhibition of GSH synthesis. These data indicated up-regulation of GSH synthesis promotes adaptation to cadmium-induced cellular stress in CP, but Zinc may confer cytoprotection independent of GSH.
\end{abstract}

Keywords: choroid plexus; cadmium; Zinc; GSH; choline; transport; cellular stress; oxidative stress

\section{Introduction}

The choroid plexus (CP) epithelia form the blood-cerebrospinal fluid (CSF) barrier. These transporting epithelia secrete CSF and selectively exchange inorganic and organic solute between blood and CSF, thereby regulating fluid/electrolyte balance, nutrient availability, and metabolite and xenobiotic clearance in CSF. CSF is continuous with the extracellular fluid surrounding neurons and glia in the brain. Thus, central neural responses to neurotransmitters and neuropeptides are contingent upon the capacity of $\mathrm{CP}$ to maintain CSF homeostasis [1-4]. Modulation of solute transport by physicochemical stressors, such as heavy metals, may compromise regulation of CSF volume and composition and disrupt central neural homeostasis.

The CP sequesters heavy metals and protects the brain from these neurotoxins $[5,6]$, potentially subjecting itself to modulation or injury by these very same agents. Metals sequestered by CP include cadmium [7-10], a toxic contaminant metal with a biological half-life of 15-30 years [11]. Given the naturally high cadmium content in tobacco plants, cigarette smoking is the predominant means of human exposure. Nonetheless, cadmium has broad industrial applications and is found in starchy root plants, mollusks, and other natural food sources $[11,12]$. Cadmium is a non-Fenton metal that can induce oxidative stress by indirectly increasing intracellular production or accumulation of free radicals and reactive species [13]. Cadmium disrupts cellular redox balance by displacing Fenton metals 
iron and copper, inhibiting complex III in the electron-transport chain, and depleting the intracellular antioxidant glutathione [14-16]. In mice, chronic cadmium exposure elicited dose-dependent changes indicative of cellular injury in CP epithelia, such as shortening and loss of microvilli and intracellular vacuole formation [10]. Investigation of the potential effects of cadmium on function, such as solute transport, is limited. We previously showed in primary cultured neonatal rat CP epithelial cells (CPECs) that subchronic exposure to $500 \mathrm{nM}$ cadmium induced an oxidative cellular stress response and stimulated apical uptake of choline [17]. Choline is a model substrate for organic cation transporter-2 (OCT-2, SLC22A2) localized to the apical membrane [18] and precursor to the neurotransmitter acetylcholine (ACh). Choline is critical for normal brain development and cognitive functions, such as learning and memory, in neonatal animals [19-21]. Stimulation of choline uptake at the apical membrane of CPECs is analogous to increased removal of choline from the CSF compartment in situ. This could potentially limit central availability of choline and ACh. CP epithelia sequester cadmium and other metals, but mechanisms that might minimize stress modulation of solute transport and other functions critical to CNS homeostasis are not fully characterized.

Glutathione (GSH) is the most abundant intracellular thiol and predominant intracellular antioxidant [22]. GSH is readily available and can directly bind cadmium. As such, it is considered the first line of defense against cadmium-induced oxidative cellular stress [23,24]. However, cadmium can deplete intracellular GSH [13,25]. We showed in CPECs that a precursor to GSH, N-acetylcysteine, attenuated induction of Hsp70 and stimulation of apical choline uptake by cadmium. Conversely, L-buthionine-sulfoximine (BSO), an inhibitor of the rate-limiting enzyme in GSH synthesis glutamate cysteine ligase (GCL), enhanced both Hsp70 induction and stimulation of choline uptake [17]. Thus, a cellular stress response was mounted in response to oxidative stress induced by cadmium. This suggested GSH might be critical to the epithelium's adaptation to cadmium-induced cellular stress. GCL is highly expressed in CP, and GSH synthesis is integral to $\gamma$-glutamyl cycling and amino acid transport [26], as well as phase II metabolism and drug clearance from CSF [27]. In CP, the antioxidant GSH system may serve to regulate accumulation of reactive oxygen species (ROS) produced by basal metabolism and ROS generated upon induction of oxidative stress, such as by elevated levels of $\mathrm{H}_{2} \mathrm{O}_{2}$ in CSF [28]. However, the role of GSH in adaptation to cellular stress elicited by cadmium or other contaminant metals sequestered by $\mathrm{CP}$ has not been fully elucidated.

Zinc, an essential mineral normally accumulated by CP [29-31], is a co-factor and structural stabilizer for enzymes, including carbonic anhydrase, which is central to CSF production $[32,33]$. Furthermore, Zinc is a redox inert metal that promotes cellular antioxidant mechanisms, protecting sulfhydryl groups from free radicals, and abridging reactive species formation through antagonism of redox-active metals; e.g., iron and copper [34]. In neurons, Zinc supplementation abates cadmium-induced oxidative cellular stress [35], and Zinc availability may regulate GSH metabolism [34,36,37]. In mice, co-treatment with Zinc protected against cadmium-induced oxidative stress in the liver, maintained GSH at levels comparable to control, and attenuated lipid peroxidation [38]. Zinc also increased expression of metallothionein (MT), which can bind cadmium and minimize subsequent disruption of cell biology and cytotoxicity [39]. Nonetheless, in MT-null mice, Zinc was protective against cadmium-induced nephrotoxicity in a GSH-dependent manner [40]. Despite marked accumulation in $\mathrm{CP}$, the capacity of Zinc to minimize cellular injury by contaminant metals or other stressors has not been investigated. Given the critical role of CP in brain homeostasis and global prevalence of deficiency in Zinc intake [41,42], elucidating the role of Zinc in CP biology is warranted.

Using primary cultured neonatal rat CPECs and isolated CP tissues exposed to submicromolar cadmium, our aim was to characterize the potentially protective roles of GSH and Zinc supplementation in the adaptive stress response to cadmium. 


\section{Results}

\subsection{Cultured Choroid Plexus Epitheial Cells (CPECs) Accumulate Cadmium (Cd) and Zinc ( $\mathrm{Zn}$ )}

Experimental treatments of CPECs and isolated CP tissues implemented in this study are described in detail in the Materials and Methods (Section 4.4) and outlined in the schematic diagram in Figure 1. Nonetheless, reporting of experimental results will include succinct descriptions of the respective treatments and references to Figure 1. The protocol used in this study to expose cells to $500 \mathrm{nM} \mathrm{CdCl}_{2}$ was similar to that implemented in our prior study of cadmium-induced effects in CPECs [17]. In the present study, we investigated whether Zinc supplementation might alter cadmium-induced responses in CPECs under conditions in which Zinc was present both before and during cadmium exposure.

We previously showed that CPECs exposed for $12 \mathrm{~h}$ to $500 \mathrm{nM} \mathrm{CdCl}_{2}$ in serum-free medium (SFM) accumulated cadmium (Cd) [17], which was consistent with accumulation of $\mathrm{Cd}$ in the choroid plexus of cadmium-exposed rodents [8-10]. In this study, we sought to determine whether CPECs supplemented with Zinc would indeed accumulate Zinc, as reported for the choroid plexus of intact rodents [29-31]. Furthermore, if Zinc were found to alter cadmium-induced effects in CPECs, this could be due in part to decreased cellular accumulation of cadmium. Therefore, we also sought to compare accumulation of Zinc and cadmium in CPECs exposed to combinations of Zinc and cadmium. For this and subsequent experiments, CPECs were maintained in maintenance medium until initiation of experimental treatment. Briefly, CPECs were first incubated for $48 \mathrm{~h}$ in maintenance medium without Zinc, to yield what will be referred to as non-supplemented cells, or in maintenance medium with $25 \mu \mathrm{M} \mathrm{ZnCl}_{2}$, to yield what will be referred to as $\mathrm{Zn}$-supplemented cells. Non-supplemented cells were then pre-treated in Zinc-free SFM for $12 \mathrm{~h}$ and divided into two sets: one set was incubated for $12 \mathrm{~h}$ in Zinc-free SFM with $0 \mathrm{CdCl}_{2}$ (Control), while the other set was exposed for $12 \mathrm{~h}$ to $500 \mathrm{nM} \mathrm{CdCl} 2$ in Zinc-free SFM (Cadmium, Cd). In parallel, Zn-supplemented cells were pre-treated in SFM with 10 $\mu \mathrm{M} \mathrm{ZnCl} 2$ and then divided into two sets: one set was incubated for $12 \mathrm{~h}$ in fresh SFM with $10 \mu \mathrm{M} \mathrm{ZnCl} 2$ (Zinc, Zn), while the other was exposed for $12 \mathrm{~h}$ to $500 \mathrm{nM} \mathrm{CdCl}_{2}$ in SFM with $10 \mathrm{ZnCl}_{2}(\mathrm{Zn}+\mathrm{Cd})($ Figure $1 \mathrm{~A})$.

Cellular content of Zinc and cadmium was measured by inductively coupled plasma mass spectrophotometry (ICP-MS) and normalized to cell protein (Table 1). In control CPECs, mean content of Zinc was $333.82 \mathrm{ng} / \mathrm{mg}$ protein, and that of cadmium was $1.02 \mathrm{ng} / \mathrm{mg}$ protein. $12 \mathrm{~h}$ cadmium exposure increased cellular cadmium content to $265.79 \mathrm{ng} / \mathrm{mg}$ protein, but Zinc content remained similar to control (348.99 ng/mg protein). Zinc supplementation increased Zinc content to $556.61 \mathrm{ng} / \mathrm{mg}$ protein $(p<0.01$ vs. Control), while cadmium content remained similar to control (1.14 $\mathrm{ng} / \mathrm{mg}$ protein). After concurrent exposure to Zinc and cadmium, Zinc content was slightly less than after exposure to Zinc alone ( $p<0.10, \mathrm{Zn}+\mathrm{Cd}$ vs. $\mathrm{Zn}$ ); cadmium content was similar to that in cells exposed to only cadmium ( $p>0.54 ; \mathrm{Zn}+\mathrm{Cd}$ vs. $\mathrm{Cd}$ ). Thus, CPECs did accumulate Zinc and cadmium and under these experimental conditions, Zinc supplementation did not attenuate cadmium accumulation, whereas cadmium exposure modestly decreased Zinc accumulation. 


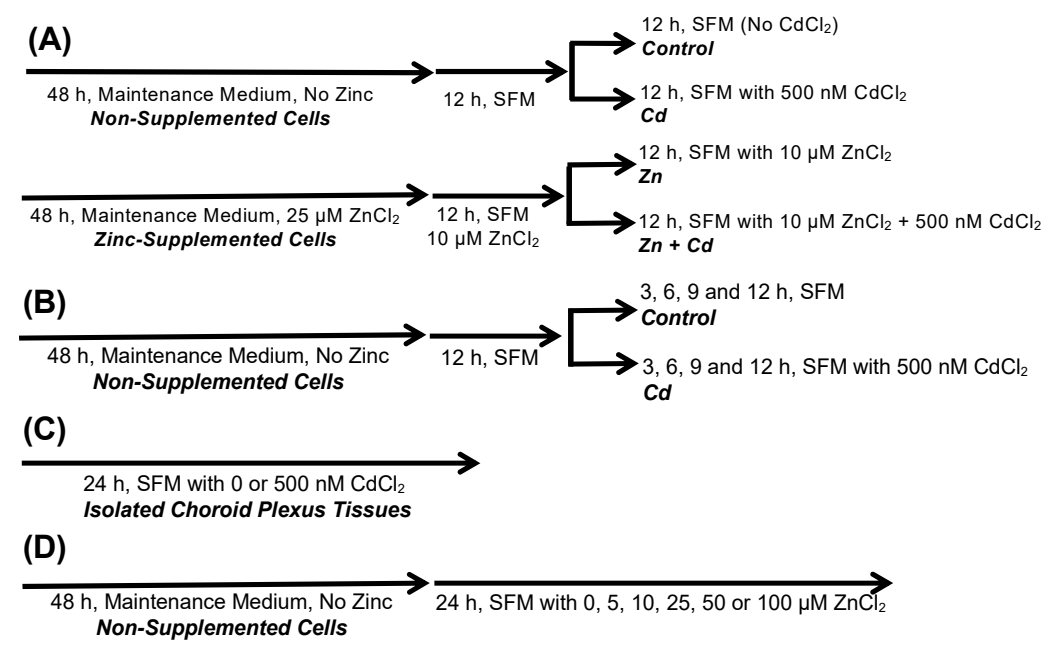

(E)

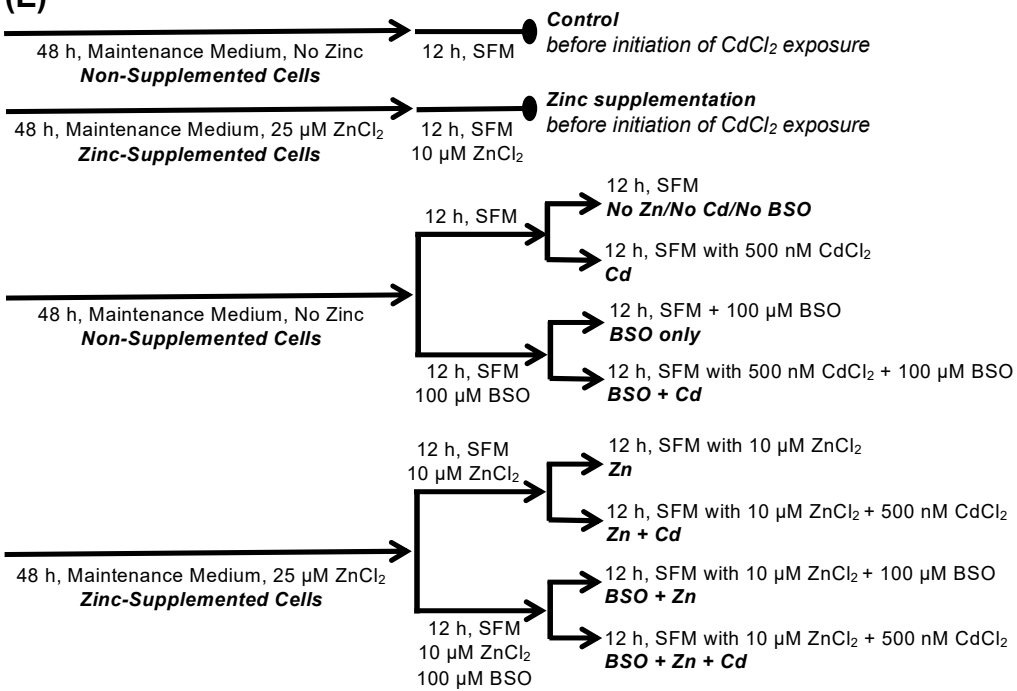

Figure 1. Schematic outlines for experimental treatments of choroid plexus epithelial cells (CPECs) or isolated choroid plexus (CP) tissues with cadmium (Cd), Zinc (Zn), and L-buthionine sulfoximine (BSO). (A) CPECs were incubated (48 h) in maintenance medium with 0 or $25 \mu \mathrm{M} \mathrm{ZnCl}_{2}$ to prepare non-supplemented versus $\mathrm{Zn}$-supplemented cells, respectively. Non-supplemented cells were then pretreated $(12 \mathrm{~h}$ ) in serum-free medium (SFM) before $12 \mathrm{~h}$ exposure in SFM to either 0 or $500 \mathrm{nM}$ $\mathrm{CdCl}_{2} ; \mathrm{Zn}$-supplemented cells were pretreated $\left(12 \mathrm{~h}\right.$ ) in SFM with $10 \mu \mathrm{M} \mathrm{ZnCl}_{2}$ before $12 \mathrm{~h}$ exposure in SFM with $10 \mu \mathrm{M} \mathrm{ZnCl}_{2}$ and either 0 or $500 \mathrm{nM} \mathrm{CdCl}_{2}$. (B) Non-supplemented CPECs were prepared and pre-treated ( $12 \mathrm{~h}, \mathrm{SFM}$ ) before $12 \mathrm{~h}$ exposure in SFM with either 0 or $500 \mathrm{nM} \mathrm{CdCl}_{2}$; cadmium and time-matched control cells were collected at 3, 6, 9, and $12 \mathrm{~h}$. (C) CP tissues from neonatal rats were isolated and incubated $(24 \mathrm{~h})$ in SFM with 0 or $500 \mathrm{nM} \mathrm{CdCl}_{2}$. (D) Non-supplemented CPECs were prepared and then incubated ( $24 \mathrm{~h}$, SFM) with 0-100 $\mu \mathrm{M} \mathrm{ZnCl}_{2}$. (E) Non-supplemented and $\mathrm{Zn}$-supplemented CPECs were prepared and exposed to cadmium in the absence or presence of BSO, an inhibitor of glutathione synthesis. Representative non-supplemented and $\mathrm{Zn}$-supplemented cells were treated (12 h) in SFM without or with $10 \mu \mathrm{M} \mathrm{ZnCl}_{2}$ respectively, but not subjected to further treatment. Other cells were treated as follows. In absence of BSO, a group of non-supplemented cells was pre-treated $(12 \mathrm{~h}, \mathrm{SFM})$ and then exposed $(12 \mathrm{~h})$ in SFM to either 0 or $500 \mathrm{nM} \mathrm{CdCl}_{2}$. In absence of BSO as well, a group of $\mathrm{Zn}$-supplemented cells was pre-treated (12 h, SFM) with $10 \mu \mathrm{M} \mathrm{ZnCl}_{2}$ and then exposed (12 h) in SFM with $10 \mu \mathrm{M} \mathrm{ZnCl}_{2}$ to either 0 or $500 \mathrm{nM} \mathrm{CdCl}_{2}$. In the presence of BSO, another group of non-supplemented cells was pre-treated (12 h) in SFM with $100 \mu \mathrm{M}$ BSO and then exposed (12 h) in SFM with $100 \mu \mathrm{M}$ BSO to either 0 or $500 \mathrm{nM} \mathrm{CdCl}_{2}$. In the presence of BSO as well, a group of Zn-supplemented cells was pre-treated (12 h) in SFM with $100 \mu \mathrm{M} \mathrm{BSO}$ and $10 \mu \mathrm{M} \mathrm{ZnCl}_{2}$ and then exposed (12 h) in SFM with $100 \mu \mathrm{M} \mathrm{BSO}$ and $10 \mu \mathrm{M} \mathrm{ZnCl}_{2}$ with either 0 or $500 \mathrm{nM} \mathrm{CdCl}_{2}$. All treatments were performed at $37^{\circ} \mathrm{C}$. 
Table 1. Elemental Zinc and elemental cadmium accumulation in choroid plexus epithelial cells (CPECs) exposed for $12 \mathrm{~h}$ to $500 \mathrm{nM} \mathrm{CdCl}_{2}$ and supplemented with Zinc.

\begin{tabular}{ccc}
\hline Condition & Zinc, $\mathbf{n g} / \mathbf{m g}$ Protein & Cadmium, ng/mg Protein \\
\hline Control & $333.82 \pm 34.04$ & $1.02 \pm 0.47$ \\
\hline Cd & $348.99 \pm 42.94$ & $265.79 \pm 11.79 *$ \\
\hline Zn & $556.61 \pm 53.44^{*}$ & $1.14 \pm 0.05$ \\
\hline Zn + Cd & $463.26 \pm 15.82 *$ & $243.72 \pm 8.62 *$ \\
\hline
\end{tabular}

CPECs were first incubated for $48 \mathrm{~h}$ in maintenance medium without Zinc; i.e., non-supplemented cells, or with $25 \mu \mathrm{M} \mathrm{ZnCl}_{2}$; i.e., $\mathrm{Zn}$-supplemented cells. Non-supplemented cells were pre-treated $(12 \mathrm{~h})$ in serum-free medium (SFM) and then divided into two sets: one set was exposed for $12 \mathrm{~h}$ in SFM with $0 \mathrm{CdCl}_{2}$ (Control), while the other was incubated for $12 \mathrm{~h}$ in SFM with $500 \mathrm{nM} \mathrm{CdCl}_{2}$ (Cd). In parallel, Zn-supplemented cells were pre-treated $\left(12 \mathrm{~h}\right.$ ) in SFM with $10 \mu \mathrm{M} \mathrm{ZnCl}_{2}$ and then divided into two sets: one set was exposed for $12 \mathrm{~h}$ in SFM with $10 \mu \mathrm{M}$ $\mathrm{ZnCl}_{2}$ alone $(\mathrm{Zn})$, while the other was exposed for $12 \mathrm{~h}$ to $500 \mathrm{nM} \mathrm{CdCl} 2$ in SFM with $10 \mu \mathrm{M} \mathrm{ZnCl}_{2}(\mathrm{Zn}+\mathrm{Cd})$. All incubations were at $37^{\circ} \mathrm{C}$. Cellular content of $\mathrm{Zn}$ and $\mathrm{Cd}$ was measured by inductively coupled plasma mass spectrophotometry (ICP-MS), normalized to cell protein, and expressed as $\mathrm{ng} / \mathrm{mg}$ protein. Metal accumulation was measured in duplicate in three separate culture preparations. Data are means \pm SE; $n=3$ culture preparations. $* p<0.05$ vs. Control.

\subsection{Cadmium Alters Intracellular Glutathione (GSH) and Glutathione Sulfide (GSSG) in CPECs}

Cadmium can deplete intracellular GSH and decrease the ratio of GSG to GSSG, which is an index of oxidized redox potential [22]. Thus, we examined whether $12 \mathrm{~h}$ exposure to $500 \mathrm{nM} \mathrm{CdCl}_{2}$ might alter GSH chemistry, and whether Zinc supplementation might modify any observed changes. We followed the same treatment protocol used to examine cellular $\mathrm{Cd}$ and $\mathrm{Zn}$ accumulation (Table 1). Non-Zinc supplemented cells were pre-treated (12 h) in SFM and then divided into two sets: one was exposed for another $12 \mathrm{~h}$ in SFM with $0 \mathrm{CdCl}_{2}$ (Control), while the other was exposed for $12 \mathrm{~h}$ to $500 \mathrm{nM} \mathrm{CdCl}_{2}$ in SFM (Cd). In parallel, Zn-supplemented cells were pre-treated (12 h) in SFM with $10 \mu \mathrm{M} \mathrm{ZnCl}_{2}$ and then divided into two sets: one was incubated for another $12 \mathrm{~h}$ in SFM with $10 \mu \mathrm{M} \mathrm{ZnCl}_{2}$ (Zn), while the other was exposed for $12 \mathrm{~h}$ to $500 \mathrm{nM} \mathrm{CdCl}_{2}$ in SFM with $10 \mu \mathrm{M} \mathrm{ZnCl}_{2}$ $(\mathrm{Zn}+\mathrm{Cd})$, (Figure 1A). We then analyzed GSH and GSSG concentrations by luminescence and calculated the ratio of GSH to GSSG (GSH:GSSG ratio; Table 2). Compared to control, cadmium exposure increased GSH and GSSG concentrations 1.75- and 7-fold $(p<0.05)$, respectively. Mean GSH:GSSG ratio in controls was 320, but was 45 in cadmium-exposed cells $(p<0.05)$. Zinc alone did not alter GSH or GSSG concentrations or GSH:GSSG ratio. Zinc also did not abate cadmium-elicited increases in GSH or GSSG or decreases in GSH:GSSG ratio. Cadmium elicited increases in GSH, suggesting that GSH synthesis was up-regulated.

Table 2. Effects of Zinc supplementation on glutathione (GSH) and glutathione sulfide (GSSG) concentrations and GSH:GSSG ratio in choroid plexus epithelial cells (CPECs) exposed to $500 \mathrm{nM}$ $\mathrm{CdCl}_{2}$ for $12 \mathrm{~h}$.

\begin{tabular}{cccc}
\hline Condition & GSH, $\mu$ M & GSSG, $\mu$ M & GSH:GSSG Ratio \\
\hline Control & $5.20 \pm 0.50$ & $0.029 \pm 0.010$ & $318.4 \pm 102.99$ \\
\hline $\mathrm{Cd}$ & $9.18 \pm 0.27^{*}$ & $0.207 \pm 0.023^{*}$ & $43.28 \pm 5.899^{*}$ \\
\hline $\mathrm{Zn}$ & $5.25 \pm 0.46$ & $0.035 \pm 0.010$ & $273.73 \pm 99.76$ \\
\hline $\mathrm{Zn}+\mathrm{Cd}$ & $7.84 \pm 0.87^{*}$ & $0.121 \pm 0.022^{*}$ & $71.94 \pm 14.97^{*}$
\end{tabular}

CPECs were first incubated for $48 \mathrm{~h}$ in maintenance medium without Zinc; i.e., non-supplemented cells, or with $25 \mu \mathrm{M} \mathrm{ZnCl}_{2}$; i.e., Zn-supplemented cells. Non-supplemented cells were pre-treated (12 h) in serum-free medium (SFM) and then divided into two sets: one set was exposed for $12 \mathrm{~h}$ in SFM (Control), while the other was exposed for $12 \mathrm{~h}$ to $500 \mathrm{nM} \mathrm{CdCl}_{2}$ in SFM (Cd). In parallel, Zn-supplemented cells were pre-treated (12 h) in SFM with $10 \mu \mathrm{M} \mathrm{ZnCl} 2$ and then divided into two sets: one set was exposed for $12 \mathrm{~h}$ in SFM with $10 \mu \mathrm{M} \mathrm{ZnCl} 2(\mathrm{Zn})$, while the other was exposed for $12 \mathrm{~h}$ to $500 \mathrm{nM} \mathrm{CdCl}_{2}$ in SFM with $10 \mu \mathrm{M} \mathrm{ZnCl}_{2}(\mathrm{Zn}+\mathrm{Cd})$. All incubations were at $37^{\circ} \mathrm{C}$. GSH and GSSG were analyzed by luminescence in triplicate in four different culture preparations $(n=4)$; GSH:GSSG ratios were calculated. Data are means $\pm \mathrm{SE} ; n=4$ culture preparations. ${ }^{*} p<0.05$ vs. Control. 


\subsection{Cadmium Induced Glutamate Cysteine Ligase (GCL) Subunits and Stress Proteins in CPECS}

Increases in GSH elicited by cadmium suggested that GSH synthesis was up-regulated. This might be a component of the collective adaptation to the cellular oxidative stress elicited by cadmium. GCL catalyzes the rate-limiting step in GSH synthesis, which is a critical regulatory point in de novo synthesis of GSH [22,43]. A catalytic subunit, GCLC, and modifier subunit, GCLM, comprise GCL. We sought to determine whether GCLC and GCLM were up-regulated within the context of the cellular stress response mounted in upon exposure to cadmium in CPECs. Thus, we analyzed time-dependent induction of GCLC and GCLM, along with heat shock protein-70 (Hsp70), heme oxygenase (HO-1), and metallothionein in non-Zinc supplemented CPECs. To this end, non-supplemented CPECs were pre-treated in SFM (12 h) and then exposed to 0 (Control) or $500 \mathrm{nM} \mathrm{CdCl}_{2}$ (Cd) in SFM for $12 \mathrm{~h}$ (Figure 1B). At 3, 6, 9, and $12 \mathrm{~h}$, representative cadmium-exposed and time-matched control cells were collected for analysis of mRNA expression for the genes encoding for GCL subunits and respective stress proteins by quantitative real-time polymerase chain reaction (qRT-PCR), and for evaluation of protein expression of GCL subunits, Hsp70, and HO-1 by immunoblot analyses.

Cadmium induced mRNA expression for rat genes encoding for heat shock protein-70 (Hspa4), heme oxygenase (Hmox1), and metallothionein (Mt1) in a time-dependent manner (Figure 2A). Hspa4 mRNA was induced 7- and 9-fold at $6 \mathrm{~h}$ and $9 \mathrm{~h}$, respectively, and was still 4 -fold greater than control at $12 \mathrm{~h}$. Hmox $1 \mathrm{mRNA}$ was induced 8-fold at $3 \mathrm{~h}$ and further increased to 70 -fold at $12 \mathrm{~h}$. Similarly, Mt1 mRNA was induced 5-fold at $3 \mathrm{~h}$ and 55 -fold at $12 \mathrm{~h}$. Cadmium treatment also induced GCL subunit gene expression (Figure 2B). The mRNA expression for the gene encoding for GCLC (Gclc) was induced 3-fold at $3 \mathrm{~h}$ and induced 5- and 7.5-fold at $9 \mathrm{~h}$ and $12 \mathrm{~h}$, respectively. The mRNA expression for the gene encoding for GCLM (Gclm) was induced 1.5-fold at $3 \mathrm{~h}$, but increased to 9-fold at $6 \mathrm{~h}$ and induced 11.5-fold at $9 \mathrm{~h}$; expression was still 8-fold greater than control at $12 \mathrm{~h}$.
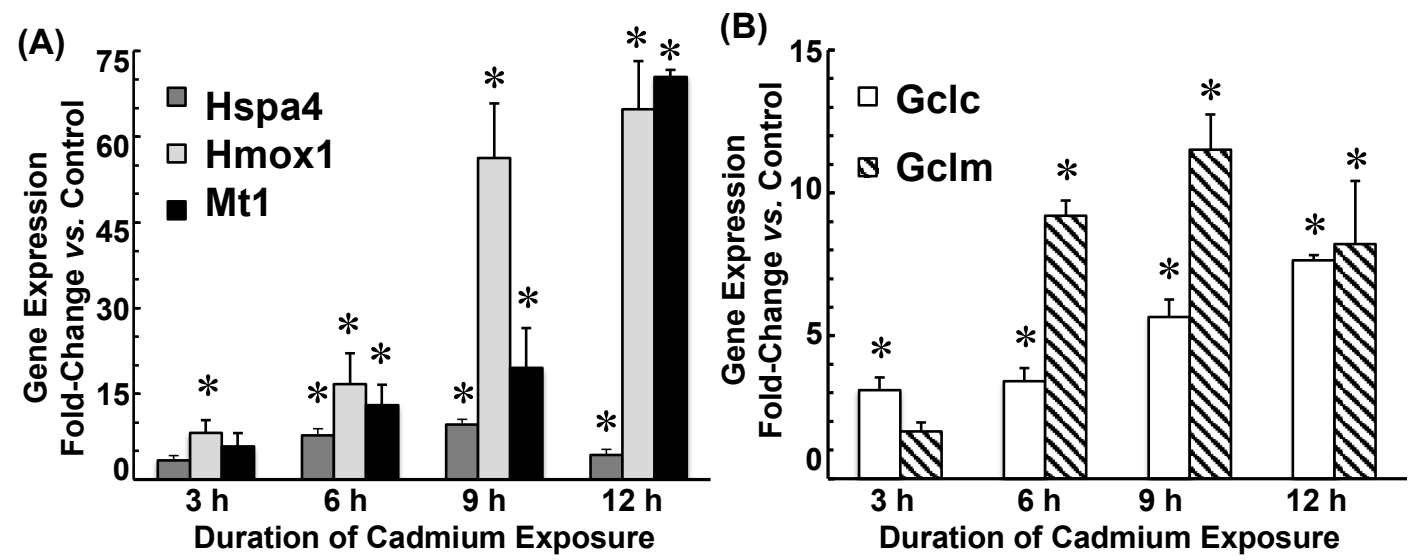

Figure 2. Time-dependent gene expression for rat heat shock protein-70 (Hspa4), heme oxygenase-1 (Hmox1), and metallothionein (Mt1) (A) and for GCLC (Gclc) and GCLM (Gclm) (B) in choroid plexus epithelial cells (CPECs) exposed to $500 \mathrm{nM} \mathrm{CdCl}_{2}$. Non-Zinc supplemented CPECs were pre-treated (12 h) in serum-free medium (SFM) and then divided into two sets: one set was incubated for $12 \mathrm{~h}$ in SFM without $\mathrm{CdCl}_{2}$ (Control), while the other was exposed for $12 \mathrm{~h}$ to $500 \mathrm{nM} \mathrm{CdCl}_{2}$ in SFM (Cd). All treatments were performed at $37^{\circ} \mathrm{C}$. At 3, 6, 9, and $12 \mathrm{~h}$, representative cadmium-exposed and time-matched control cells were collected for analysis of mRNA expression by quantitative real-time polymerase chain reaction (qRT-PCR); mRNA expression for each test gene was normalized to mRNA for rat $\beta$-actin (Actb) and GAPDH (Gapdh). Fold-induction was calculated as the ratio of normalized gene expression in Cd-exposed cells to that in time-matched controls. mRNA was analyzed in triplicate in five separate culture preparations. Data are means $\pm \mathrm{SE} ; n=5$; ${ }^{*} p<0.05$ vs. time-matched Control.

Protein expression of Hsp70, HO-1, and GCLM was also induced by cadmium (Figure 3). Hsp70 was induced 3-fold at $6 \mathrm{~h}$ through $9 \mathrm{~h}$ and remained elevated (4.5-fold) at $12 \mathrm{~h}$. HO- 1 was induced 2.5 -fold at $3 \mathrm{~h}$ and increased incrementally to 12 -fold greater 
than control at $12 \mathrm{~h}$ (Figure 3A). GCLC protein expression was similar to control for the $12 \mathrm{~h}$ duration of cadmium exposure $(p>0.50)$, whereas GCLM protein was induced 2-fold after $12 \mathrm{~h}$ of exposure (Figure 3B).

(A)

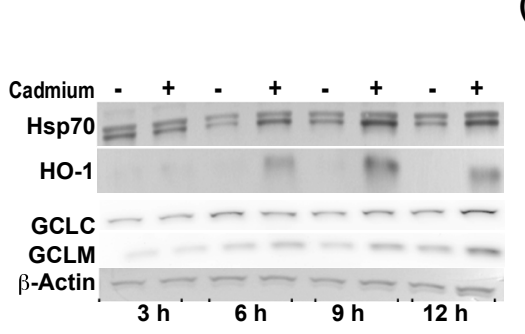

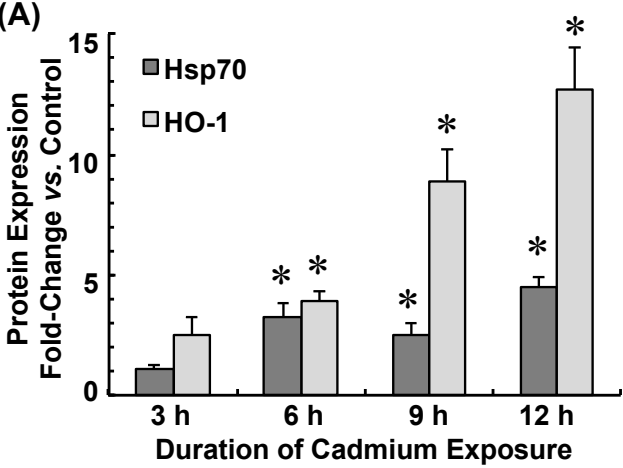

(B)

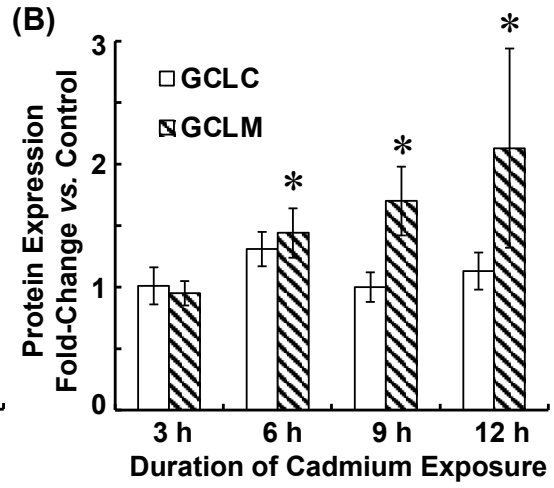

Figure 3. Time-dependent heat shock protein-70 (Hsp70) and heme oxygenase (HO-1) protein expression (A) and GCLC and GCLM protein expression (B) in choroid plexus epithelial cells exposed to $500 \mathrm{nM} \mathrm{CdCl}_{2}$. Non-Zinc supplemented cells were pre-treated $(12 \mathrm{~h})$ in serum-free medium (SFM) and divided into two sets: one set was incubated in SFM without $\mathrm{CdCl}_{2}$, while the other was exposed to $500 \mathrm{nM} \mathrm{CdCl}_{2}$ in SFM (Cd). All treatments were performed at $37^{\circ} \mathrm{C}$. At $3,6,9$, and $12 \mathrm{~h}$, representative cadmium-exposed and time-matched control cells were collected for immunoblot analysis of proteins of interest and $\beta$-actin. A representative immunoblot is shown. Immunoreactivity of each protein with the respective primary antibody was visualized by colorimetric or enhanced chemiluminescence detection. Protein band intensity was normalized to that of $\beta$-actin; induction was expressed as fold-change versus time-matched control. Protein expression was analyzed in five separate culture preparations; data are means $\pm \mathrm{SE} ; n=5 .{ }^{*} p<0.05$ vs. time-matched Control.

Induction of stress protein and GCL subunit gene expression was examined in isolated neonatal CP to determine whether a similar response could be elicited in the intact tissues. Lateral and fourth CP tissues isolated from neonatal rats and incubated with 0 (Control) or $500 \mathrm{nM} \mathrm{CdCl} 2$ (Cadmium) in SFM for $24 \mathrm{~h}$ (Figure 1C). Given the complex organization of epithelial cells and vascular tissues (endothelial, smooth muscle) of the intact choroid plexus versus the monolayer of epithelial cells in CPECs, we extended the exposure time to $24 \mathrm{~h}$ versus the $12 \mathrm{~h}$ exposure time for single-layered CPECs. In cadmium-treated tissues, mRNA expression of Hspa4, Hmox1, Gclc, and Gclm were twice those in controls; Mt1 gene expression was 9 times that in controls $(p<0.05$, Figure 4$)$.

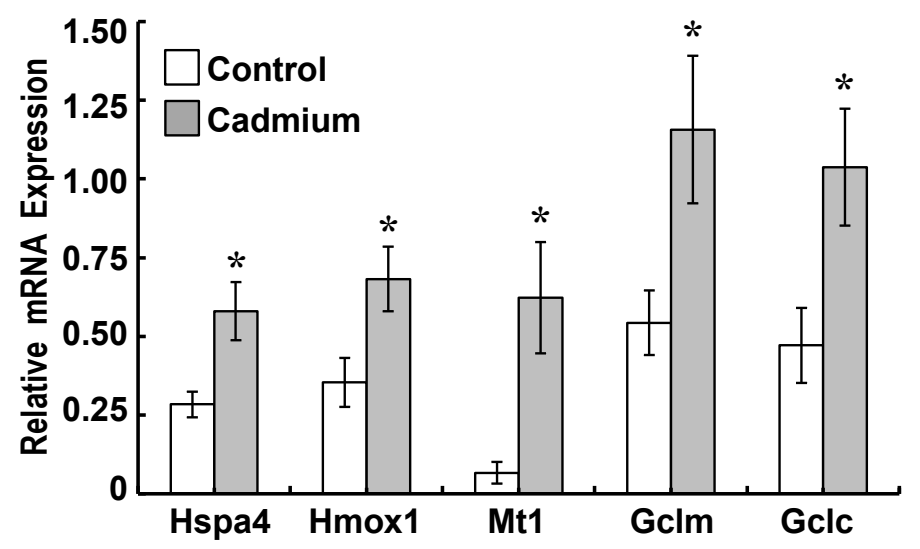

Figure 4. Gene expression for rat heat shock protein-70 (Hspa4), heme oxygenase (Hmox1), metallothionein (Mt1), GCLM (Gclm), and GCLC (Gclc) in isolated neonatal rat lateral and fourth choroid plexus (CP) tissues exposed in vitro to cadmium. Lateral and fourth $\mathrm{CP}$ tissues from four neonatal rats were harvested and pooled; this comprised a single sample (i.e., $n=1)$. Each set of tissues was 
incubated in serum-free medium (SFM) with 0 or $500 \mathrm{nM} \mathrm{CdCl}_{2}$ for $24 \mathrm{~h}\left(37^{\circ} \mathrm{C}\right)$. The mRNA was analyzed in triplicate by qualitative RT-PCR in six separate sets of CP tissues. The mRNA expression for each test gene was normalized to mRNA for rat $\beta$-actin (Actb) and GAPDH (Gapdh). Values are expressed as relative mRNA expression for control and cadmium-treated tissues. Data are means $\pm \mathrm{SE} ; n=6$ sets of tissues. ${ }^{*} p<0.05$ vs. Control.

\subsection{Zinc Attenuates Increases in Apical Choline Uptake in Cadmium-Exposed CPECS}

We assessed to what extent treatment with Zinc alone might alter apical choline uptake. CEPCs were incubated in maintenance medium not supplemented with $\mathrm{ZnCl}_{2}$ (i.e., non-supplemented cells) and then treated $\left(37^{\circ} \mathrm{C}\right)$ for $24 \mathrm{~h}$ in SFM containing 0 (Control) or 5-100 $\mu \mathrm{M} \mathrm{ZnCl}_{2}$ (Figure 1D). After experimental treatment, we assayed $30 \mathrm{~min}$ apical uptake of $10 \mu \mathrm{M}\left[{ }^{3} \mathrm{H}\right]$ choline $\pm 750 \mu \mathrm{M}$ hemicholinium-3 (HC-3) in Zinc-free artificial cerebrospinal fluid (aCSF) at $37^{\circ} \mathrm{C}$ (Table 3). Thirty-minute choline uptake was $3274.27 \pm \mathrm{SE}$ $287.13 \mathrm{pmol} / \mathrm{mg}$ protein in controls $(n=3)$. Pre-treatment with $5-50 \mu \mathrm{M} \mathrm{ZnCl}_{2}$ did not alter choline uptake ( $p>0.72$ ), but treatment with $100 \mu \mathrm{M} \mathrm{ZnCl}_{2}$ decreased uptake by $90 \%$ $(p<0.05$ vs. Control).

Table 3. Thirty-minute apical uptake of $10 \mu \mathrm{M}\left[{ }^{3} \mathrm{H}\right]$ choline in choroid plexus epithelial cells (CPECs) after $24 \mathrm{~h}$ pre-treatment with $5-100 \mu \mathrm{M} \mathrm{ZnCl}_{2}$ in serum-free medium (SFM).

\begin{tabular}{cc}
\hline Zinc Concentration, $\mu \mathbf{M}$ & {$\left[{ }^{3} \mathbf{H}\right]$ Choline Uptake, pmol/mg Protein } \\
\hline $0($ Control $)$ & $3274.27 \pm 287.13$ \\
\hline 5 & $3373.58 \pm 227.32$ \\
\hline 10 & $3288.23 \pm 201.05$ \\
\hline 25 & $3343.04 \pm 269.76$ \\
\hline 50 & $3339.53 \pm 175.93$ \\
\hline 100 & $304.07 \pm 96.00^{*}$
\end{tabular}

CPECs were incubated ( $24 \mathrm{~h}$ ) in SFM supplemented with 0 (Control) or 5-100 $\mu \mathrm{M} \mathrm{ZnCl}_{2}$ at $37^{\circ} \mathrm{C}$. Cells were then rinsed and incubated $\left(30 \mathrm{~min}, 37^{\circ} \mathrm{C}\right)$ in Zinc-free artificial cerebrospinal fluid (10 $\mathrm{mM}$ Tris-HEPES, pH 7.4) with $10 \mu \mathrm{M}\left[{ }^{3} \mathrm{H}\right]$ choline chloride $\pm 750 \mu \mathrm{M}$ hemicholinium-3. Thirty-minute $\left[{ }^{3} \mathrm{H}\right]$ choline uptake was expressed as $\mathrm{pmol} / \mathrm{mg}$ protein. Uptake was measured in triplicate in three different culture preparations. Data are means $\pm \mathrm{SE} ; n=3{ }^{*} p<0.05$ vs. Control.

Subsequently, we examined the potential for Zinc supplementation to disrupt cadmiumelicited stimulation of apical choline uptake in CPECs by comparing choline uptake in non-supplemented cells exposed for $12 \mathrm{~h}$ to $500 \mathrm{nM} \mathrm{CdCl}_{2}$ to that in $\mathrm{Zn}$-supplemented cells exposed for $12 \mathrm{~h}$ to $500 \mathrm{nM} \mathrm{CdCl}_{2}$ (Figure 1A). We followed the same treatment protocol used to examine cellular $\mathrm{Cd}$ and $\mathrm{Zn}$ accumulation (Table 1) and GSH chemistry (Table 2). Non-Zinc supplemented cells were pre-treated (12 h) in SFM and divided into two sets: one was incubated for $12 \mathrm{~h}$ in SFM (Control), while the other was exposed for $12 \mathrm{~h}$ to $500 \mathrm{nM}$ $\mathrm{CdCl}_{2}$ in SFM (Cd). In parallel, Zn-supplemented cells were pre-treated (12 h) in SFM with $10 \mu \mathrm{M} \mathrm{ZnCl} 2$ and divided into two sets: one was incubated for $12 \mathrm{~h}$ in SFM with $10 \mu \mathrm{M}$ $\mathrm{ZnCl}_{2}(\mathrm{Zn})$, while the other was exposed for $12 \mathrm{~h}$ to $500 \mathrm{nM} \mathrm{CdCl}_{2}$ in SFM with $10 \mu \mathrm{M}$ $\mathrm{ZnCl}_{2}(\mathrm{Zn}+\mathrm{Cd})$ (Figure 1A). Following experimental treatment, $30 \mathrm{~min}$ apical uptake of $10 \mu \mathrm{M}\left[{ }^{3} \mathrm{H}\right]$ choline $( \pm 750 \mu \mathrm{M} \mathrm{HC}-3)$ was assayed in aCSF free of cadmium and Zinc (Figure 5). Compared to control, cadmium increased choline uptake by $60 \%(p<0.05)$, but Zinc alone had no effect. However, Zinc supplementation abated stimulation of choline uptake by cadmium $(p<0.05, \mathrm{Zn}+\mathrm{Cd}$ vs. $\mathrm{Cd})$, such that uptake was comparable to control $(p>0.34)$. 


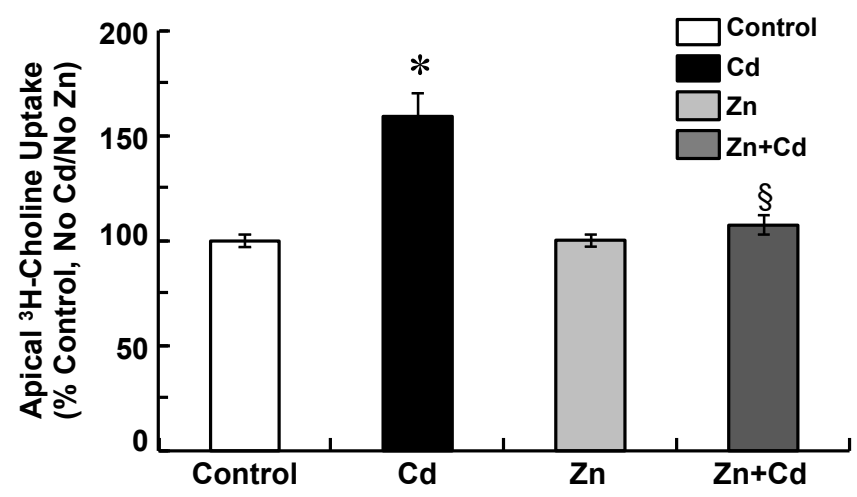

Figure 5. Thirty-minute apical uptake of $10 \mu \mathrm{M}\left[{ }^{3} \mathrm{H}\right]$ choline in Zinc-supplemented choroid plexus epithelial cells (CPECs) exposed for $12 \mathrm{~h}$ to $500 \mathrm{nM} \mathrm{CdCl}_{2}$. CPECs were first incubated for $48 \mathrm{~h}$ in maintenance medium without Zinc, i.e., non-supplemented cells, or with $25 \mu \mathrm{M} \mathrm{ZnCl}_{2}$, i.e., $\mathrm{Zn}$ supplemented cells. Non-supplemented cells were then pre-treated (12 h) in SFM and divided into two sets: one was incubated for $12 \mathrm{~h}$ in SFM with $0 \mathrm{CdCl}_{2}$ (Control), while the other was exposed for $12 \mathrm{~h}$ to $500 \mathrm{nM} \mathrm{CdCl}_{2}$ in SFM (Cd). In parallel, Zn-supplemented cells were pre-treated (12 h) in SFM with $10 \mu \mathrm{M} \mathrm{ZnCl}_{2}$ and divided into two sets: one set was exposed for $12 \mathrm{~h}$ in SFM with $10 \mu \mathrm{M} \mathrm{ZnCl}_{2}$ (Zn), while the other was exposed for $12 \mathrm{~h}$ to $500 \mathrm{nM} \mathrm{CdCl}_{2}$ in SFM with $10 \mu \mathrm{M} \mathrm{ZnCl}_{2}(\mathrm{Zn}+\mathrm{Cd})$. All treatments were at $37^{\circ} \mathrm{C}$. After experimental treatments, cells were rinsed and incubated (30 min, $\left.37^{\circ} \mathrm{C}\right)$ in artificial CSF $\left(10 \mathrm{mM}\right.$ Tris-HEPES, pH 7.4) with $10 \mu \mathrm{M}\left[{ }^{3} \mathrm{H}\right]$ choline chloride $\pm 750 \mu \mathrm{M}$ hemicholinium-3. Uptake was measured in triplicate in three different culture preparations $(n=3)$. Uptake was expressed as percentage of control; data are means $\pm \mathrm{SE} ; n=3$. ${ }^{*} p<0.05$ vs. Control. $\S$ $p<0.05$ vs. Cd.

2.5. Zinc Supplementation and Inhibition of GSH Synthesis Modify Cellular Stress Responses and Apical Choline Uptake in Cadmium-Exposed CPECs

Based on increases in GSH and induction of GCL subunits elicited by cadmium, we reasoned that up-regulation of GSH synthesis facilitated adaptation to cadmium-induced cellular stress. Thus, we predicted that inhibiting GSH synthesis to remove this component of adaptation would lead to compensatory increases in induction of heat shock protein70 , heme oxygenase, and metallothionein. Nonetheless, Zinc supplementation did not modulate GSH synthesis or prevent decreases in GSH:GSSG ratio by cadmium, but did attenuate stimulation of apical choline uptake in cadmium-exposed CPECs. Our prior work indicated stimulation of apical choline uptake in CPECs was associated with induction of the cellular oxidative stress response [17]. Thus, we predicted Zinc supplementation would still diminish cadmium-elicited stimulation of choline uptake and stress protein induction, if GSH synthesis were inhibited. To test these predictions, we used L-buthionine sulfoximine (BSO) to inhibit GCL [44] in Zn-supplemented and non-supplemented CPECs exposed to cadmium. This would permit evaluation of the efficacy of Zinc to modify the cellular stress response and attenuate stimulation of apical choline uptake in cadmiumtreated CPECs despite attenuation of GSH synthesis (Figure 1E).

For these experiments, CPECs were first incubated for $48 \mathrm{~h}$ in maintenance medium without Zinc; i.e., non-supplemented cells, or with $25 \mu \mathrm{M} \mathrm{ZnCl}_{2}$; i.e., $\mathrm{Zn}$-supplemented cells. To test the effects of cadmium and Zinc supplementation under conditions in which GSH synthesis was inhibited before and during cadmium exposure, $100 \mu \mathrm{M}$ BSO was added to SFM used for pre-treatment and cadmium exposure of non-supplemented and Zn-supplemented CPECs. In the absence of BSO, a group of non-supplemented cells was pre-treated (12 h) in SFM and then divided into two sets; one was incubated for $12 \mathrm{~h}$ in SFM without cadmium (Control), while the other was exposed for $12 \mathrm{~h}$ to $500 \mathrm{nM} \mathrm{CdCl}_{2}$ in SFM (Cd). In the absence of BSO as well, a group of Zn-supplemented cells was pre-treated (12h) in SFM with $10 \mu \mathrm{M} \mathrm{ZnCl} 2$ and then divided into two sets: one was incubated for $12 \mathrm{~h}$

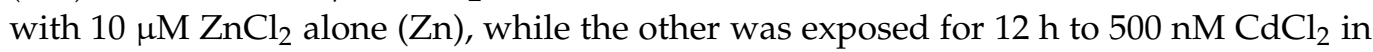


SFM with $10 \mu \mathrm{M} \mathrm{ZnCl}_{2}(\mathrm{Zn}+\mathrm{Cd})$. After experimental treatments, cells were processed for analysis of GSH chemistry, gene expression, and apical choline uptake.

We assayed GSH and GSSG by luminescence and calculated the GSH:GSSG ratio (Table 4). Compared to control, cadmium increased GSH and GSSG concentrations $(4.39 \pm 0.727 \mu \mathrm{M}$ vs. $9.35 \pm 1.38 \mu \mathrm{M}$ and $0.050 \pm 0.017$ vs. $0.167 \pm 0.012 \mu \mathrm{M}$, respectively) and decreased the GSH:GSSG ratio ( 232 vs. 47; $p<0.05$ ); however, Zinc alone had no effect. Zinc supplementation did not prevent the increases in GSH and GSSG concentrations or the decrease in GSH:GSSG ratio elicited by cadmium. BSO alone decreased GSH concentration $90 \%$, without increasing GSSG; the GSH:GSSG ratio was decreased to 8.7 ( $p<0.05$ vs. Control). In the presence of BSO, treatments with cadmium or Zinc did not alter GSSG concentration or the GSH:GSSG ratio versus BSO alone. Cadmium alone increased GSH, but in the presence of BSO, cadmium decreased GSH by $50 \%$ versus $\mathrm{BSO}$ alone $(p<0.03)$. In presence of BSO, Zinc did not alter GSH concentration versus BSO alone. In Zinc-supplemented cells exposed to cadmium with BSO, GSH concentration was similar to that in non-supplemented cells treated with cadmium and BSO.

Table 4. Effects of Zinc supplementation and inhibition of glutathione (GSH) synthesis by Lbuthionine sulfoximine (BSO) on GSH and glutathione sulfide (GSSG) concentrations and the GSH:GSSG ratio in choroid plexus epithelial cells (CEPCs) exposed for $12 \mathrm{~h}$ to $500 \mathrm{nM} \mathrm{CdCl}_{2}$.

\begin{tabular}{cccc}
\hline Condition & GSH, $\mu \mathrm{M}$ & GSSG, $\mu \mathrm{M}$ & GSH:GSSG Ratio \\
\hline Control & $4.39 \pm 0.727$ & $0.050 \pm 0.017$ & $231.76 \pm 121.66$ \\
Cd & $9.35 \pm 1.38^{*}$ & $0.167 \pm 0.012^{*}$ & $46.90 \pm 5.68^{*}$ \\
Zn & $4.57 \pm 0.70$ & $0.045 \pm 0.025$ & $241.33 \pm 130.55$ \\
$\mathrm{Zn}+\mathrm{Cd}$ & $8.11 \pm 1.12^{*}$ & $0.135 \pm 0.030^{*}$ & $54.09 \pm 8.14^{*}$ \\
$\mathrm{BSO}$ & $0.45 \pm 0.50^{*}$ & $0.073 \pm 0.031$ & $8.75 \pm 3.25^{*}$ \\
$\mathrm{BSO}+\mathrm{Cd}$ & $0.23 \pm 0.02^{*} \S$ & $0.077 \pm 0.023$ & $9.37 \pm 3.29^{*}$ \\
$\mathrm{BSO}+\mathrm{Zn}$ & $0.51 \pm 0.07^{*}$ & $0.074 \pm 0.021$ & $6.86 \pm 2.26^{*}$ \\
$\mathrm{BSO}+\mathrm{Zn}+\mathrm{Cd}$ & $0.33 \pm 0.02^{*} \S$ & $0.078 \pm 0.025$ & $8.09 \pm 3.09^{*}$
\end{tabular}

CPECs were first incubated $(48 \mathrm{~h})$ in maintenance medium without Zinc; i.e., non-supplemented cells, or with $25 \mu \mathrm{M} \mathrm{ZnCl} 2$; i.e., $\mathrm{Zn}$-supplemented cells. In the absence of $\mathrm{BSO}$, a group of non-supplemented cells was pretreated $(12 \mathrm{~h})$ in serum-free medium (SFM) and then divided into two sets; one was incubated (12 h) in SFM without cadmium (Control), while the other was exposed (12 h) to $500 \mathrm{nM} \mathrm{CdCl}_{2}$ in SFM (Cd). In absence of BSO as well, a group of $\mathrm{Zn}$-supplemented cells was pre-treated (12 h) in SFM with $10 \mu \mathrm{M} \mathrm{ZnCl}_{2}$ and then divided into two sets: one was incubated (12 h) with $10 \mu \mathrm{M} \mathrm{ZnCl}_{2}(\mathrm{Zn})$, while the other was exposed $(12 \mathrm{~h})$ to $500 \mathrm{nM}$ $\mathrm{CdCl}_{2}$ in SFM with $10 \mu \mathrm{M} \mathrm{ZnCl}_{2}(\mathrm{Zn}+\mathrm{Cd})$. In the presence of BSO, a group of non-supplemented CPECs was pre-treated (12 h) in SFM with $100 \mu \mathrm{M}$ BSO and then divided into two sets; one was incubated (12 h) in SFM with $100 \mu \mathrm{M}$ BSO (BSO), while the other was exposed (12 h) to $500 \mathrm{nM} \mathrm{CdCl}_{2}$ in SFM with $100 \mu \mathrm{M}$ BSO (BSO $+\mathrm{Cd})$. In the presence of BSO as well, a group of $\mathrm{Zn}$-supplemented cells was pre-treated $(12 \mathrm{~h})$ in SFM with $100 \mu \mathrm{M}$ BSO and $10 \mu \mathrm{M} \mathrm{ZnCl}_{2}$ and then divided into two sets: one set was incubated (12 h) with $100 \mu \mathrm{M} \mathrm{BSO}$ and $10 \mu \mathrm{M} \mathrm{ZnCl}_{2}(\mathrm{BSO}+\mathrm{Zn}$ ); the other was exposed (12 h) to $500 \mathrm{nM} \mathrm{CdCl} 2$ in SFM $100 \mu \mathrm{M} \mathrm{BSO}$ and $10 \mu \mathrm{M}$ $\mathrm{ZnCl}_{2}(\mathrm{BSO}+\mathrm{Zn}+\mathrm{Cd})$. All treatments were performed at $37^{\circ} \mathrm{C}$. GSH and GSSG concentrations were analyzed by luminescence in triplicate in four different culture preparations; ratios of GSH to GSSG (GSH:GSSG ratio) were subsequently calculated. Data are means $\pm \mathrm{SE} ; n=4 .{ }^{*} p<0.05$ vs. Control; $\S p<0.05$ vs. BSO alone.

To examine whether gene expression of stress proteins and GCL subunits were possibly up-regulated by Zinc supplementation prior to cadmium exposure, mRNA was analyzed in representative non-supplemented and $\mathrm{Zn}$-supplemented CPECs. Briefly, representative non-supplemented CPECs were treated in SFM for $12 \mathrm{~h}$, but not subjected to further treatments with BSO, Zinc, or cadmium; in parallel, representative Zn-supplemented cells were treated in SFM with $10 \mu \mathrm{M} \mathrm{ZnCl}_{2}$ for $12 \mathrm{~h}$, but not subjected to further treatment with BSO or cadmium (Figure 1E). Thereafter, Hspa4, Hmox1, Mt1, and GCL subunit (Gclc and Gclm) mRNA expression was analyzed by qRT-PCR in Zn-supplemented and time-matched control cells (Figure 6A). Prior to cadmium exposure, Zinc supplementation did not alter Hspa4, Hmox1, Gclc, or Gclm mRNA ( $p>0.10$ vs. Control), but increased Mt1 mRNA nearly 19-fold ( $p<0.03$ vs. Control). Stress protein and GCL subunit gene expression was also analyzed in non-supplemented and Zn-supplemented CPECs exposed to cadmium (12 h) without or with inhibition of GSH synthesis by BSO (Figure 6B,C). Cadmium alone induced Hspa4 mRNA 2.75-fold, whereas in Zn-supplemented cells, 
cadmium did not induce Hspa4 mRNA expression; Zinc supplementation itself did not induce Hspa4 mRNA. Though BSO alone did not induce Hspa4 mRNA, it did enhance Hspa 4 mRNA induction by cadmium to 10 times that in control. In Zn-supplemented cells exposed to cadmium with BSO, Hspa4 mRNA was induced at levels similar to those in cells exposed to only cadmium. In Zinc-supplemented cells treated with BSO, Hspa4 mRNA levels were similar to non-treated controls.
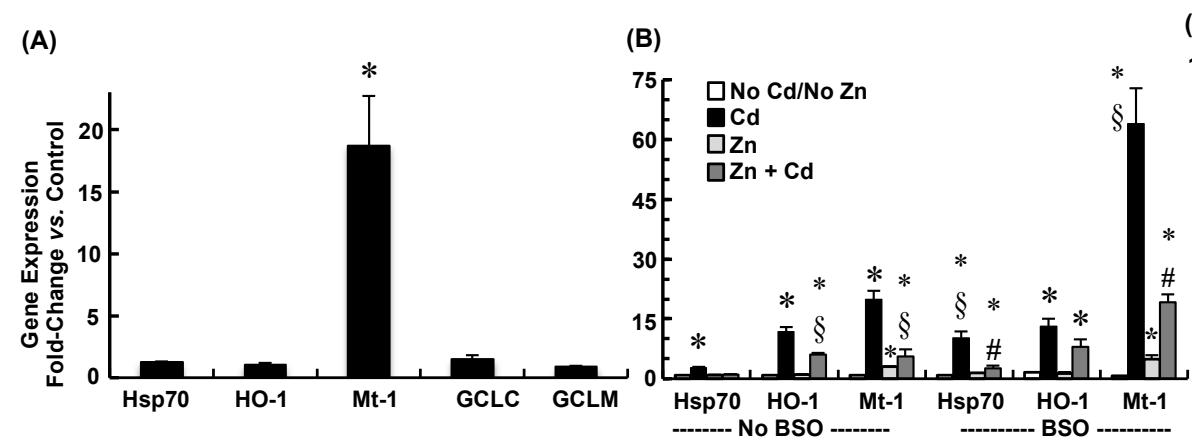

(C)

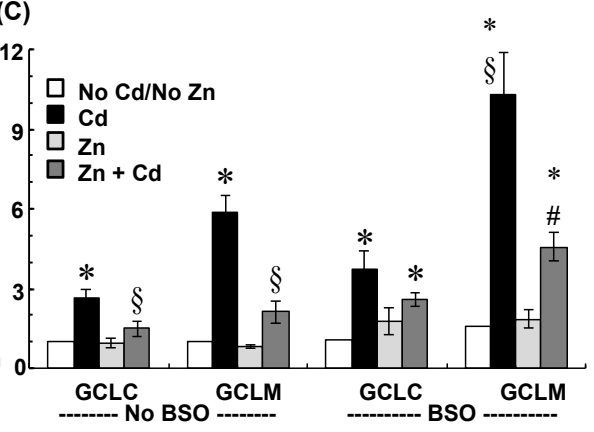

Figure 6. Effects of Zinc supplementation and inhibition of glutathione synthesis by L-buthionine sulfoximine (BSO) on gene expression for rat heat shock protein-70 (Hspa4), heme oxygenase (Hmox1), metallothionein (Mt1), GCLC (Gclc), and GCLM (Gclm) expression in choroid plexus epithelial cells (CPECs) exposed for $12 \mathrm{~h}$ to $500 \mathrm{nM} \mathrm{CdCl}_{2}$. CPECs were first incubated $(48 \mathrm{~h})$ in maintenance medium without $\mathrm{Zinc}$; i.e., non-supplemented cells, or with $25 \mu \mathrm{M} \mathrm{ZnCl}_{2}$; i.e., Zn-supplemented cells. (A) A representative group of non-supplemented CPECs was treated in serum-free medium (SFM) for $12 \mathrm{~h}$, but not subjected to further treatment; in parallel, representative Zn-supplemented cells were treated in SFM with $10 \mu \mathrm{M} \mathrm{ZnCl}_{2}$ for $12 \mathrm{~h}$, but not subjected to further treatment. (B,C) In the absence of BSO (-No BSO-), a group of non-supplemented cells was pre-treated $(12 \mathrm{~h})$ in SFM and then divided into two sets; one set was incubated (12 h) in SFM without cadmium (No Cd/No Zn), while the other was exposed (12 h) to $500 \mathrm{nM} \mathrm{CdCl}_{2}$ in SFM (Cd). In absence of BSO as well (-No BSO-), a group of Zn-supplemented cells was pre-treated (12 h) in SFM with $10 \mu \mathrm{M} \mathrm{ZnCl}_{2}$ and then divided into two sets: one set was incubated (12 h) in SFM with $10 \mu \mathrm{M} \mathrm{ZnCl}_{2}$ (Zn), while the other was exposed (12 h) to $500 \mathrm{nM} \mathrm{CdCl}_{2}$ in SFM with $10 \mu \mathrm{M} \mathrm{ZnCl}_{2}(\mathrm{Zn}+\mathrm{Cd})$. To test the effects of inhibition of glutathione synthesis, BSO was added to the SFM used for pre-treatment and $\mathrm{CdCl}_{2}$ exposure of non-supplemented and Zn-supplemented CPECs. In the presence of BSO (-BSO-), a group of non-supplemented cells was pre-treated $(12 \mathrm{~h})$ in SFM with $100 \mu \mathrm{M}$ BSO and divided into two sets: one was incubated (12 h) in SFM with $100 \mu \mathrm{M}$ BSO (BSO, No Cd/No Zn), while the other set was exposed (12 h) to $500 \mathrm{nM} \mathrm{CdCl}_{2}$ in SFM with $100 \mu \mathrm{M} \mathrm{BSO}(\mathrm{BSO}+\mathrm{Cd})$. In the presence of BSO as well, (-BSO-), a group of Zn-supplemented cells was pre-treated $(12 \mathrm{~h})$ in SFM with $100 \mu \mathrm{M}$ BSO and $10 \mu \mathrm{M} \mathrm{ZnCl}_{2}$ and then divided into two sets: one was incubated $\left(12 \mathrm{~h}\right.$ ) with $100 \mu \mathrm{M} \mathrm{BSO}$ and $10 \mu \mathrm{M} \mathrm{ZnCl} 2(\mathrm{BSO}+\mathrm{Zn})$; the other was exposed $(12 \mathrm{~h})$ to $500 \mathrm{nM} \mathrm{CdCl}_{2}$ in SFM $100 \mu \mathrm{M}$ BSO and $10 \mu \mathrm{M} \mathrm{ZnCl}_{2}(\mathrm{BSO}+\mathrm{Zn}+\mathrm{Cd})$. All treatments were performed at $37^{\circ} \mathrm{C}$. The mRNA expression was analyzed in triplicate by quantitative real-time polymerase chain reaction (qRT-PCR); mRNA expression for each test gene was normalized to mRNA for rat $\beta$-actin (Actb) and GAPDH (Gapdh). Fold-induction was calculated as the ratio of normalized gene expression in Cd-exposed cells to that in time-matched controls. The mRNA was analyzed in triplicate in five separate culture preparations. Data are presented as means $\pm \mathrm{SE} ; n=5 ;{ }^{*} p<0.05$ vs. Control; $\S p<0.05$ vs. Cd; $\# p<0.05 \mathrm{Zn}+\mathrm{BSO}+\mathrm{Cd}$ vs. $\mathrm{BSO}+\mathrm{Cd}$.

Hmox1 mRNA was induced 11-fold by cadmium. While in Zn-supplemented cells exposed to cadmium Hmox1 mRNA levels exceeded controls, the levels were still less than in cells exposed to only cadmium ( $p<0.01 ; \mathrm{Zn}+\mathrm{Cd}$ vs. Cd). BSO alone did not induce Hmox1 mRNA, and slightly enhanced Hmox1 mRNA induction by cadmium. In Zn-supplemented cells exposed to cadmium with BSO, Hmox1 mRNA levels were similar to those in cells exposed to cadmium alone.

Mt1 mRNA was induced 20-fold by cadmium, whereas in Zn-supplemented cells, cadmium induced Mt1 mRNA 6-fold. BSO alone did not induce Mt1 mRNA, but enhanced cadmium-elicited induction of Mt1 mRNA to levels 60 times greater than control. However, in Zn-supplemented cells, BSO did not enhance Mt-1 induction by cadmium; gene expression was comparable to that in cells exposed to cadmium alone $(p>0.45 ; \mathrm{BSO}+\mathrm{Zn}+\mathrm{Cd}$ vs. Cd). 
As compared to control, Gclc and Gclm mRNA levels were induced 2.6- and 5-fold by cadmium exposure (Figure $6 \mathrm{C} ; p<0.01$ ), but not by Zinc. Supplementation with Zinc attenuated induction of Gclc and Gclm mRNA by cadmium $(p<0.02)$. BSO alone did not induce Gclc and Glcm mRNA, but markedly enhanced Gclm mRNA induction by cadmium $(p<0.05 ; \mathrm{BSO}+\mathrm{Cd}$ vs. Cd) without altering Gclc induction. In Zn-supplemented cells, BSO did not enhance Glcm mRNA induction by cadmium; expression was comparable to that in cells exposed to cadmium alone $(p>0.37)$.

Finally, apical choline uptake was compared among CPECs treated with combinations of cadmium, Zinc, and BSO (Figure 7). As compared to control, cadmium increased choline uptake by $62 \%(p<0.01)$, and in the presence of $\mathrm{BSO}$, cadmium increased uptake by $106 \%$ $(p<0.01)$. In the absence or presence of BSO, Zinc supplementation completely attenuated stimulation of uptake by cadmium, such that uptake was similar to that in control $(p>0.45)$. Neither BSO nor Zinc alone altered choline uptake.

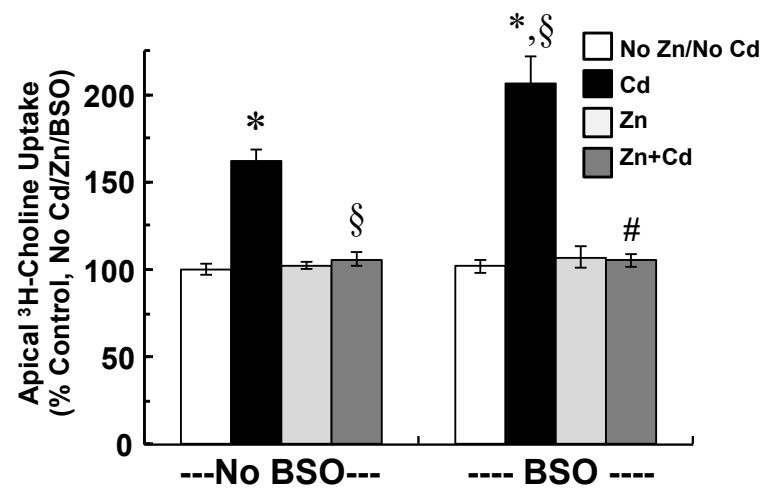

Figure 7. Effects of inhibition of glutathione (GSH) synthesis by L-buthionine sulfoximine (BSO) and Zinc supplementation on apical uptake of $10 \mu \mathrm{M}\left[{ }^{3} \mathrm{H}\right]$ choline in choroid plexus epithelial cells (CPECs) exposed for $12 \mathrm{~h}$ to $500 \mathrm{nM} \mathrm{CdcCl}_{2}$. CPECs were first incubated $(48 \mathrm{~h})$ in maintenance medium without Zinc; i.e., non-supplemented cells, or with $25 \mu \mathrm{M} \mathrm{ZnCl}_{2}$; i.e., Zn-supplemented cells. In the absence of BSO (-No BSO-), a group of non-supplemented cells was pre-treated (12 h) in serum-free medium (SFM) and then divided into two sets; one set was incubated (12 h) in SFM without cadmium (No Cd/No Zn), while the other was exposed (12 h) to $500 \mathrm{nM} \mathrm{CdCl}_{2}$ in SFM (Cd). In absence of BSO as well (-No BSO-), a group of Zn-supplemented cells was pre-treated $(12 \mathrm{~h})$ in SFM with $10 \mu \mathrm{M} \mathrm{ZnCl}$ and then divided into two sets: one set was incubated (12 h) in SFM with $10 \mu \mathrm{M} \mathrm{ZnCl}$ (Zn), while the other was exposed (12 h) to $500 \mathrm{nM} \mathrm{CdCl}_{2}$ in SFM with $10 \mu \mathrm{M} \mathrm{ZnCl} 2(\mathrm{Zn}+\mathrm{Cd})$. To test the effects of GSH inhibition, BSO was added to the SFM used for pre-treatment and cadmium exposure of CPECs. In the presence of BSO (-BSO-): a group of non-supplemented cells was pre-treated $(12 \mathrm{~h})$ in SFM with $100 \mu \mathrm{M}$ BSO and divided into two sets: one set was incubated (12 h) in SFM with $100 \mu \mathrm{M}$ BSO (BSO, No Cd/No Zn), while the other was exposed $(12 \mathrm{~h})$ to $500 \mathrm{nM} \mathrm{CdCl}_{2}$ in SFM with $100 \mu \mathrm{M} \mathrm{BSO}(\mathrm{BSO}+\mathrm{Cd})$. In the presence of BSO as well (-BSO-), a group of Zn-supplemented cells was pre-treated (12 h) in SFM with $100 \mu \mathrm{M}$ BSO and $10 \mu \mathrm{M} \mathrm{ZnCl}_{2}$ and then divided into two sets: one was incubated (12 h) with $100 \mu \mathrm{M}$ BSO and $10 \mu \mathrm{M} \mathrm{ZnCl} 2(\mathrm{BSO}+\mathrm{Zn})$, while the other was exposed $(12 \mathrm{~h})$ to $500 \mathrm{nM} \mathrm{CdCl}_{2}$ in SFM with $100 \mu \mathrm{M}$ $\mathrm{BSO}$ and $10 \mu \mathrm{M} \mathrm{ZnCl}_{2}(\mathrm{BSO}+\mathrm{Zn}+\mathrm{Cd})$. All treatments were performed at $37^{\circ} \mathrm{C}$. After experimental treatments, cells were rinsed and incubated $\left(30 \mathrm{~min}, 37^{\circ} \mathrm{C}\right)$ in artificial CSF $(10 \mathrm{mM}$ Tris-HEPES, $\mathrm{pH}$ 7.4) with $10 \mu \mathrm{M}\left[{ }^{3} \mathrm{H}\right]$ choline chloride $\pm 750 \mu \mathrm{M}$ hemicholinium-3. Artificial CSF did not contain $\mathrm{BSO}, \mathrm{Zinc}$, or cadmium. Uptake was measured in triplicate in three different culture preparations $(n=3)$. Uptake was expressed as percentage of that in control; data are means $\pm \mathrm{SE} ; n=3 .{ }^{*} p<0.05$ vs. Control; $\S p<0.05$ vs. Cd; ${ }^{\#} p<0.05 \mathrm{Zn}+\mathrm{BSO}+\mathrm{Cd}$ vs. $\mathrm{BSO}+\mathrm{Cd}$.

\section{Discussion}

Our prior study in primary cultures of neonatal rat CPECs showed that low, nonlethal cadmium exposure induced cellular stress and increased choline uptake across the apical or CSF membrane [17]. The main findings in this study were as follows. First, 
at a non-lethal dose, cadmium decreased the GSH:GSSG ratio and elicited an adaptive stress response marked by stress protein induction and up-regulation of GSH synthesis. Second, Zinc supplementation conferred CPECs cytoprotection against cadmium, including attenuation of cadmium-elicited modulation of choline transport. Third, efficacy of Zinc to protect a critical physiological function, such as solute transport, was sustained despite decreased GSH.

In CPECs, exposure to sub-micromolar cadmium elicited a stress response marked by stress protein induction and up-regulation of GSH synthesis and decreased the ratio of reduced GSH to GSSG. This was consistent with induction of oxidative stress [22]. Comparable in vitro exposure of isolated $\mathrm{CP}$ tissues to cadmium also elicited induction of stress protein and GCL subunit gene expression. Cadmium indeed can deplete intracellular GSH $[13,25]$. For example, $25 \mu \mathrm{M}$ cadmium exposure decreases GSH in HepG2 cells [45]. Nevertheless, exposure to sub-micromolar cadmium increased GSH in rat mesangial cells [46], as did exposures to cadmium as high as $40 \mu \mathrm{M}$ in rat lung fibroblasts and human H441 bronchiolar cells [47,48]. GSH and GSH:GSSG ratio are assayed typically only after experimental treatment, as done in this study. Analyses of GSH over the course of in vitro and in vivo cadmium exposures indicate GSH may decrease initially but gradually return to or exceed pre-exposure values [49-51]. As GSH scavenges ROS, GSH concentration decreases; this alleviates inhibition of GCL and permits de novo replenishment of GSH [22,43]. This may explain our observation in CPECs that were treated with BSO to inhibit GCL and diminish GSH synthesis; in that case, cadmium no longer increased GSH, but actually decreased it. This suggests that cadmium elicited increases in GSH via up-regulation of de novo synthesis in CPECs. Newly synthesized GSH may help manage the oxidative load and directly bind cadmium, thereby dampening the severity of structural or functional injury of the epithelium by cadmium. As shown in HepG2 cells, treatment with $\alpha$-lipoic acid to regenerate GSH alleviated cadmium cytotoxicity [45].

Cadmium induced both the GCLC and GCLM of GCL, the catalyst of the rate-limiting step and regulatory point in de novo synthesis of GSH [22]. Induction of GCLC gene and protein expression in response to cadmium-elicited oxidative cellular stress has been established [48,52]. Induction of GCLM by metals or cellular stress has not been characterized extensively but can be induced under conditions of oxidative stress [22]. A study in mouse lung demonstrated induction of GCLM by quantum dots with cadmium as the core constituent [53]. GCLM also is induced under conditions of oxidative cellular stress [22]. In mouse hepatoma cells, tert-butylhydroquinone elicited oxidative stress and maximally induced gene expression of GCLM 10-fold, and that of GCLC 2-fold [48]. In cadmiumtreated CPECs, regulation of GCL also was predominantly transcriptional, and induction of GCLM was more pronounced than that of GCLC. Thus, in CP, a low-dose cadmium exposure may increase GSH synthesis in part through induction of both GCL subunits.

As is characteristic of cellular stress responses to cadmium [13,54], cadmium elicited incremental induction of HO-1 and Mt-1 and biphasic induction of Hsp70 in CPECs. Cadmium also markedly induced Hmox1, Mt1, and Hspa4 mRNA in isolated neonatal $\mathrm{CP}$ tissues. Nonetheless, there was greater induction of Hsp70 mRNA and protein and Mt1 mRNA and enhanced stimulation of choline uptake in cells exposed to cadmium in presence of BSO. This indicated that up-regulation of GCL subunits and GSH synthesis was integral to the adaptive response to cadmium. GSH can directly bind cadmium and lower its effective concentration, but also scavenge free radicals and regulate the oxidative load $[23,24,55]$. Inhibiting the cell's ability to replenish GSH might have resulted in greater ROS accumulation, which would accentuate cellular stress and stress protein induction. GCL activity in rat CP is greater than that in various brain regions [26], and despite its small size, CP produces and secretes a significant fraction of GSH in CSF [44]. GSH plays central roles in amino acid transport, drug metabolism, and CSF clearance [26,27]. Furthermore, the GSH antioxidant system in CP appears integral in regulating the ROS load generated at baseline and additional ROS generated by oxidative injury, such as increased $\mathrm{H}_{2} \mathrm{O}_{2}$ in CSF [28]. Our findings support that postulate. 
Supplementing CPECs with Zinc conferred cytoprotection against cadmium. Although Zinc did not prevent decreases in the GSH:GSSG ratio elicited by cadmium, the induction of HO-1 and Mt-1 were less pronounced. Furthermore, Hsp70 was not induced, and apical choline uptake was no longer stimulated. Induction of Hsp70 is triggered by protein unfolding and proportional to severity of cellular stress $[56,57]$. Thus, the decreased Hsp70 induction in Zinc-supplemented cells suggested that Zinc facilitated adaptation to or lessened the severity of cadmium-elicited stress. Prior and sustained Zinc treatment can protect against cadmium-induced cellular injury or dysfunction by various mechanisms [34,47]. In testis interstitial cells, Zinc impaired cadmium-induced carcinogenesis in part by increasing cellular efflux of cadmium [58]. In pulmonary epithelia, Zinc lessened cadmium toxicity by inhibiting cadmium influx via Zinc importer ZIP8 (SLC39A8) [59]. However, similar to our observations in CPECs, others have reported that in H441 bronchial epithelial cells, Zinc supplementation enhanced cadmium resistance without decreasing cellular accumulation of cadmium [47]. Cadmium induces HO-1 transcription via activation and subsequent nuclear export of the transcriptional repressor of HO-1 Bach1 [60]. In CPECs, HO-1 gene induction persisted in cells exposed dually to cadmium and Zinc, indicating Zinc did not broadly disrupt physical or molecular interactions of cadmium within the cell. Although Zinc did not decrease total cadmium accumulation in CPECs, Zinc may minimize effects of cadmium by modulating subcellular cadmium distribution [58].

Preconditioning cells or tissues with non-lethal physicochemical stress sufficient to cause protein unfolding, and thus signal heat shock protein (hsp) induction, may preserve morphological and functional integrity, including the capacity to transport solute against a subsequent stress of comparable or greater severity [61-63]. Treating rats with Zinc at doses sufficient to induce Hsp70, Hsp90, and Hsp38 enhanced cadmium tolerance in cultured renal proximal tubules isolated from treated rats [64]. In cultured flounder renal proximal tubule, $6 \mathrm{~h}$ of exposure to $100 \mu \mathrm{M} \mathrm{ZnCl}_{2}$ with recovery protected net transepithelial sulfate secretion against subsequent severe heat shock or chemical stress as a consequence of hsp induction [62]. As we previously showed in isolated shark $\mathrm{CP}, \mathrm{Hsp} 70$ induction was essential to sustain net transepithelial organic anion transport following $6 \mathrm{~h}$ of exposure to $50 \mu \mathrm{M} \mathrm{ZnCl}_{2}$ [65]. CP sensitivity to Zinc may vary with species. Here, in rat CPECs, exposure to as much as $50 \mu \mathrm{M} \mathrm{ZnCl}_{2}$ did not stimulate or impair choline uptake, and extended treatments with $25 \mu \mathrm{M}$ and $10 \mu \mathrm{M} \mathrm{ZnCl}_{2}$ did not induce Hsp70 in rat CPECs. Although induction of Hsp70 per se was not the predominant mechanism of Zinc cytoprotection, induction of Hsp70 was a critical component of the integrative and adaptive cellular stress response in cadmium-exposed CPECs. Indeed, in non-supplemented and Zinc-supplemented cells, when GSH synthesis was inhibited by $\mathrm{BSO}$, there was a compensatory increased induction of the heat shock protein.

Alternatively, Zinc can facilitate cytoprotection by regulating GSH metabolism [34,36]. In brains of fetal rats of marginally Zinc-deficient dams and IMR-32 neuroblastoma cells maintained in Zinc-deficient media, GCLC and GCLM gene and protein expression and GSH levels were decreased. Zinc-deficient culture conditions also exacerbated susceptibility to dopamine-induced oxidative stress and impeded up-regulation of GSH synthesis, likely due to impaired NRF2 activation [34,37]. Conversely, Zinc supplementation can bolster GSH metabolism. Treating rats with cadmium and Zinc increased liver GSH levels and ratios of GSH to GSSG and decreased liver GSSG levels, as compared to treatment with only cadmium [66]. In retinal pigment epithelial cells, $5 \mu \mathrm{M} \mathrm{ZnCl}_{2}$ increased GCLC and GLCM gene expression and GSH levels [67]. However, in CPECs, micromolar $\mathrm{ZnCl}_{2}$ did not increase GSH synthesis, induce GCL subunits, or disrupt up-regulation of GSH chemistry by cadmium. Furthermore, in Zinc-supplemented CPECs in which GSH synthesis was impaired by BSO, the induction of Hsp70, HO-1, and Mt-1 by cadmium was no longer accentuated, and stimulation of choline uptake was still diminished. Thus, Zinc can facilitate adaptation to cellular stress to a low-dose cadmium exposure in a manner independent of GSH status. 
Zinc supplementation markedly induced metallothionein (Mt1) mRNA expression. Though not elucidated here, increased metallothionein (MT) protein expression before cadmium exposure is a possible mechanism by which Zinc facilitated stress adaptation and abated modulation of apical choline uptake in CPECs. In primary mouse hepatocytes, Zinc pretreatment to induce MT expression before chemical induction of oxidative stress with ferric nitriloacetate minimized cellular stress despite GSH depletion with BSO [68]. This method has also been shown to curtail cellular injury by cadmium and other agents, such as acetaminophen, in the liver [68-70]. MT directly binds Zinc, and in coordination with Zinc transporters, regulates free cytosolic Zinc and its distribution among specific subcellular compartments and Zinc-dependent enzymes [34,39,71]. Supplementation increases intracellular Zinc and signals synthesis of new MT that can bind additional Zinc. MT binds up to seven Zinc ions, but in normal redox balance not all metal-binding sites are occupied. The protein has even greater affinity for cadmium. Thus, if MT were up-regulated before cadmium exposure, it could bind cadmium and decrease its effective concentration [55]. MT also scavenges and thereby regulates accumulation of ROS produced as cadmium inhibits electron transport and displaces Fenton metals [72]. Although Zinc is redox inert, Zinc-thiol binding within MT is redox-sensitive. Under oxidizing conditions such as that induced by cadmium, Zinc may be released and then function in varying capacities to facilitate redox signaling and antioxidant defenses [39]. A more targeted investigation of MT in Zinc-mediated adaptation to cellular stress elicited by cadmium in CP is warranted, but is beyond the scope of the current study.

\section{Materials and Methods}

\subsection{Animal Use and Tissue Harvest}

With approval from the Institutional Animal Care and Use Committee at Texas A\&M University (protocol no. 2011-128), choroid plexus (CP) tissues were harvested from 2-3-day-old neonatal Sprague-Dawley rats obtained from time-pregnant dams (Charles River, Roanoke, IL, USA). On gestational day 16, dams were acquired and maintained in a $12 \mathrm{~h}$ light/dark cycle with free access to regular chow and water. For each primary culture preparation, lateral and fourth $\mathrm{CP}$ tissues were harvested from 36-50 neonatal rat brains with sterile instruments and pooled and initially maintained in chilled collection medium. For in vitro experiments in isolated intact $\mathrm{CP}$, tissues from neonatal rats also were pooled and maintained initially in chilled collection medium.

\subsection{Chemicals, Reagents, and Solutions}

All chemicals were analytical grade and purchased from commercial vendors. Critical reagents and kits were purchased from the following vendors: $\mathrm{CdCl}_{2}$ and $\mathrm{ZnCl}_{2}$, Sigma (St. Louis, MO, USA); L-buthionine sulfoximine, Acros Organics (Morris Plains, NJ, USA); and GSH/GSSG-Glo ${ }^{\mathrm{TM}}$ Assay (Promega, Madison, WI, USA). The collection medium consisted of sterile DMEM/F12 medium with 100 units penicillin per $100 \mathrm{~mL}$. The dissociation buffer contained (in mM) $137 \mathrm{NaCl}, 2.7 \mathrm{KCl}, 0.7 \mathrm{Na}_{2} \mathrm{HPO}_{4}, 5.6$ glucose, 10 HEPES (pH 7.4), $5 \mathrm{U} / \mathrm{mL}$ protease (Sigma, St. Louis, MO, USA), and $1500 \mathrm{kU} / \mathrm{mL}$ DNase I (CalbiochemEMD Millipore, Billerica, MA, USA). The plating medium consisted of minimum essential medium with D-valine substituted for L-valine (U.S. Biological, Swampscott, MA, USA), 10\% NuSerum IV (BD Biosciences, San José, CA, USA), $100 \mathrm{ng} / \mathrm{mL}$ PGE1, $10 \mu \mathrm{M}$ forskolin, $1.5 \mu \mathrm{M}$ triiodothyronine, and $50 \mathrm{ng} / \mathrm{mL}$ EGF; growth factors were tissue culture grade and purchased from Sigma (St. Louis, MO, USA). The maintenance medium consisted of DMEM-F12 with 5\% NuSerum IV and listed growth factors at the same concentrations. Plating and maintenance media were antibiotic- and fungicide-free. Stock solutions of $\sim 1.5 \mathrm{mM} \mathrm{CdCl}_{2}$ in sterile ultra-pure water were prepared bi-weekly and diluted serially to a final concentration of $500 \mathrm{nM} \mathrm{CdCl}_{2}$ in sterile serum-free DMEM/F12 to prepare treatment media the day cadmium exposure was initiated. Stock solutions of $\sim 3 \mathrm{mM} \mathrm{ZnCl}_{2}$ and stock solutions of $\sim 75 \mathrm{mM} \mathrm{BSO}$ in sterile ultrapure water were prepared weekly and used directly to make treatment media. The radiolabeled choline transport was assayed in artificial 
cerebrospinal fluid (aCSF) containing (in mM) 137.4 sodium, 3 potassium, 1.4 calcium, 0.8 magnesium, 0.7 phosphate, 125.4 chloride, 2 urea, 18 bicarbonate, and 10 TRIS/HEPES (pH 7.4) with $12 \mathrm{mM}$ glucose, $10 \mu \mathrm{M}$ unlabeled choline chloride (Tokyo Chemical Industry, Tokyo, Japan), and trace $\left[{ }^{3} \mathrm{H}\right]$ choline chloride $(0.075 \mu \mathrm{Ci}, \sim 80 \mathrm{Ci} / \mathrm{mmol}$; Perkin-Elmer, Waltham, MA, USA). For protein analysis, the cell lysis buffer contained $50 \mathrm{mM}$ TRIS-HCl $\mathrm{pH} 6.8,100 \mathrm{mM}$ dithiothreitol, 30\% v/v glycerol, $2 \% w / v$ SDS, $0.05 \% v / v$ Triton X-100, and $0.5 \% w / v$ bromophenol blue; the stripping solution contained $25 \mathrm{mM}$ glycine- $\mathrm{HCl}, 1 \% \mathrm{w} / v$ SDS (pH 2). Hank's Balanced Salt Solution (HBSS), phosphate-buffered saline (PBS), and TRIS-buffered saline (TBS) of standard compositions were used for various assays.

\subsection{Isolation and Primary Culture of Choroid Plexus Epithelial Cells (CPECs)}

Epithelial cells were isolated from neonatal rat CP tissues by enzymatic and mechanical disruption and cultured by an aseptic technique, as described previously $[17,73,74]$. Briefly, tissues suspended in dissociation buffer were shaken $\left(37^{\circ} \mathrm{C}\right.$ water bath) and triturated intermittently over a $20 \mathrm{~min}$ period. The mixture of released cells and extraneous tissue was filtered through a sterile $100 \mu \mathrm{M}$ mesh cell strainer (BD Biosciences, San José, CA, USA). The filtrate was centrifuged, and pelleted cells were washed with penicillin-supplemented DMEM/F12. Cells were suspended in penicillin-supplemented DMEM/F12 with 10\% NuSerum IV and pre-plated in a $35 \mathrm{~mm}$ Petri dish for $3.5 \mathrm{~h}$ at $37^{\circ} \mathrm{C}$ (humidified $95 \%$ air $/ 5 \%$ $\mathrm{CO}_{2}$ ); during this time extraneous fibroblasts attached, thereby minimizing fibroblast contamination of the CP epithelial cell culture. Unattached epithelial cells then were suspended in plating medium, plated on impermeable supports; i.e., non-coated sterile polystyrene tissue culture plates (Corning, Suwanee, GA, USA), at $3 \times 10^{5}$ cells $/ \mathrm{cm}^{2}$ in $300 \mu \mathrm{L}$ medium $/ \mathrm{cm}^{2}$ plating surface, and incubated $\left(37^{\circ} \mathrm{C}\right.$; humidified $95 \%$ air $\left./ 5 \% \mathrm{CO}_{2}\right)$. The base of plating medium was MEM with D-valine substituted for L-valine; D-valine is poorly metabolized by fibroblasts, which limits fibroblast survival and proliferation; this further minimized fibroblast contamination of CP epithelial primary cultures [75]. After $72 \mathrm{~h}$, plating medium and unattached cells were removed and replaced with maintenance medium; thereafter, medium was replaced every two days until start of experimental treatment. CPECs formed fully differentiated confluent monolayers within 6 days, and experiments were initiated 6-9 days post-plating. Cells remained in maintenance medium until initiation of experimental treatments.

\subsection{Treatment of CPECs and Isolated CP Tissues with Cadmium, Zinc, and BSO}

CPECs were maintained in complete maintenance medium until initiation of experimental treatment. To study the effects of cadmium in CPECs, cells were exposed to $500 \mathrm{nM}$ $\mathrm{CdCl}_{2}$ for $12 \mathrm{~h}$. We selected this concentration and duration of cadmium exposure based our prior investigation of time-dependent and concentration-dependent exposure of CPECs to $0-1000 \mathrm{nM} \mathrm{CdCl}_{2}$ [17]. Twelve-hour exposure to $500 \mathrm{nM} \mathrm{CdCl}_{2}$ induced a cellular stress response and marked stimulation in apical choline uptake, but did not increase lactate dehydrogenase release; i.e., caused minimal cytotoxicity. The protocol for Zinc treatment was based on a series of experiments that determined a non-toxic dose of Zinc after 48 and $72 \mathrm{~h}$ of incubation.

Experimental treatments of CPECs and isolated CP tissues implemented in this study are described here in detail and are outlined in a schematic diagram in Figure 7. All treatments were performed at $37{ }^{\circ} \mathrm{C}$ (humidified $95 \%$ air $/ 5 \% \mathrm{CO}_{2}$ ). The potential for Zinc supplementation to modify cadmium-induced responses in CPECs was examined under conditions in which Zinc was present both before and during cadmium exposure. As shown in Figure 1A, CPECs were first incubated for $48 \mathrm{~h}$ in maintenance medium without Zinc supplement; these cells were designated as non-supplemented cells. In parallel, another group of CPECs was incubated for $48 \mathrm{~h}$ in maintenance medium with $25 \mu \mathrm{M} \mathrm{ZnCl}_{2}$; these cells were designated as Zn-supplemented cells. Non-supplemented cells were then pre-treated in Zinc-free SFM for $12 \mathrm{~h}$ and divided into two sets: one set was incubated for $12 \mathrm{~h}$ in fresh Zinc-free SFM with $0 \mathrm{CdCl}_{2}$ (Control), while the other set was exposed for 12 
$\mathrm{h}$ to $500 \mathrm{nM} \mathrm{CdCl} 2$ in fresh Zinc-free SFM (Cadmium, Cd). In parallel, Zn-supplemented cells were pre-treated in SFM with $10 \mu \mathrm{M} \mathrm{ZnCl}_{2}$ and then divided into two sets: one set was incubated for $12 \mathrm{~h}$ in fresh SFM with $10 \mu \mathrm{M} \mathrm{ZnCl}_{2}$ (Zinc, Zn), while the other was exposed for $12 \mathrm{~h}$ to $500 \mathrm{nM} \mathrm{CdCl}_{2}$ in SFM with $10 \mathrm{ZnCl}_{2}(\mathrm{Zn}+\mathrm{Cd}$ ) (Figure $1 \mathrm{~A})$.

Time-dependent induction of GCLC, GCLM, and stress protein mRNA and protein expression were analyzed in non-Zinc supplemented CPECs exposed to cadmium. CPECs were first incubated for $48 \mathrm{~h}$ in complete maintenance medium without Zinc supplement; i.e., non-supplemented cells. These cells were subsequently pre-treated for $12 \mathrm{~h}$ in SFM and then exposed to 0 (Control) or $500 \mathrm{nM} \mathrm{CdCl}_{2}$ (Cd) in SFM for up to $12 \mathrm{~h}$ (Figure 1B). At 3, 6, 9 , and $12 \mathrm{~h}$, representative cadmium-exposed and time-matched control cells were collected for analysis of mRNA and protein expression by quantitative real-time polymerase chain reaction or immunoblot analysis, respectively.

To investigate in vitro effects of cadmium in intact $\mathrm{CP}$, lateral and fourth $\mathrm{CP}$ tissues from four neonatal rats were harvested and pooled; this comprised a single sample (i.e., $n=1$ ). Each set of tissues was collected initially in penicillin-supplemented DMEMF12 without serum and then rinsed generously with sterile penicillin-supplemented PBS $(600 \mathrm{mg} / 100 \mathrm{~mL})$. Tissues were transferred onto a pre-wetted polycarbonate permeable cell support (Thermo Scientific-Nunc, Waltham, MA, USA) in a well of a sterile 6-well plate with $4 \mathrm{~mL} \mathrm{SFM}$ to equilibrate $\left(2 \mathrm{~h}, 37^{\circ} \mathrm{C}\right.$; humidified $95 \%$ air $\left./ 5 \% \mathrm{CO}_{2}\right)$. Equilibration medium was replaced with $4 \mathrm{~mL} \mathrm{SFM} \mathrm{with} 0$ or $500 \mathrm{nM} \mathrm{CdCl}_{2}$; tissues were incubated for $24 \mathrm{~h}\left(37^{\circ} \mathrm{C}\right.$; humidified 95\% air $\left./ 5 \% \mathrm{CO}_{2}\right)$ (Figure $\left.1 \mathrm{C}\right)$.

Time-dependent effects of Zinc on apical $\left[{ }^{3} \mathrm{H}\right]$ choline uptake were examined in CPECs that were first incubated for $48 \mathrm{~h}$ in maintenance medium not supplemented with $\mathrm{ZnCl}_{2}$. Representative cells were subsequently treated for $24 \mathrm{~h}$ in SFM containing 0 (Control), 5 , $10,25,50$, or $100 \mu \mathrm{M} \mathrm{ZnCl}_{2}$ (Figure 1D).

To characterize the role of GSH in cellular responses to cadmium and Zinc supplementation, non-Zinc-supplemented and Zinc-supplemented cells were treated with the gamma-cysteine ligase inhibitor, L-buthionine sulfoximine (BSO) (Figure 1E). We used $100 \mu \mathrm{M}$ BSO in our prior study of the effects of cadmium in CPECs [17]. Studies in Tlymphocytes had indicated BSO was effective in the range of 10-100 $\mu \mathrm{M}$ [76]. CPECs were first incubated for $48 \mathrm{~h}$ in maintenance medium without Zinc; i.e., non-supplemented cells, or with $25 \mu \mathrm{M} \mathrm{ZnCl}_{2}$; i.e., $\mathrm{Zn}$-supplemented cells. To test the effects of cadmium and Zinc supplementation under conditions in which GSH synthesis was inhibited before and during cadmium exposure, $100 \mu \mathrm{M}$ BSO was added to the SFM used for pre-treatment and cadmium exposure of non-supplemented and Zn-supplemented CPECs. In the absence of $\mathrm{BSO}$, a group of non-supplemented cells was pre-treated (12 h) in SFM and then divided into two sets; one was incubated for $12 \mathrm{~h}$ in SFM without cadmium (Control), while the other was exposed for $12 \mathrm{~h}$ to $500 \mathrm{nM} \mathrm{CdCl}_{2}$ in SFM (Cd). Also in absence of BSO, a group of Zn-supplemented cells was pre-treated (12h) in SFM with $10 \mu \mathrm{M} \mathrm{ZnCl}_{2}$ and then divided into two sets: one was incubated for $12 \mathrm{~h}$ with $10 \mu \mathrm{M} \mathrm{ZnCl}_{2}$ alone $(\mathrm{Zn})$, while the other was exposed for $12 \mathrm{~h}$ to $500 \mathrm{nM} \mathrm{CdCl}_{2}$ in SFM with $10 \mu \mathrm{M} \mathrm{ZnCl}_{2}(\mathrm{Zn}+\mathrm{Cd})$. In the presence of BSO, another group of non-supplemented cells was pre-treated (12 h) in SFM with $100 \mu \mathrm{M}$ BSO and then divided into two sets; one set was incubated for $12 \mathrm{~h}$ in SFM without cadmium (BSO), while the other was exposed for $12 \mathrm{~h}$ to $500 \mathrm{nM} \mathrm{CdCl}_{2}$ in SFM with $100 \mu \mathrm{M}$ BSO $(\mathrm{BSO}+\mathrm{Cd}$ ). In the presence of $\mathrm{BSO}$ as well, a group of $\mathrm{Zn}$-supplemented cells was pre-treated (12 h) in SFM with $100 \mu \mathrm{M} \mathrm{BSO}$ and $10 \mu \mathrm{M} \mathrm{ZnCl} 2$ and then divided into two sets; one set was exposed (12 h) in SFM with $100 \mu \mathrm{M} \mathrm{BSO}$ and $10 \mu \mathrm{M} \mathrm{ZnCl}_{2}$ and no cadmium $(\mathrm{BSO}+\mathrm{Zn})$, while the other was exposed $(12 \mathrm{~h})$ to $500 \mathrm{nM} \mathrm{CdCl}_{2}$ in SFM with $100 \mu \mathrm{M}$ BSO and $10 \mu \mathrm{M} \mathrm{ZnCl}_{2}(\mathrm{BSO}+\mathrm{Zn}+\mathrm{Cd})$. All treatments were performed at $37^{\circ} \mathrm{C}$. After treatment, cells were processed for analysis of glutathione chemistry, mRNA expression, and apical uptake of $\left[{ }^{3} \mathrm{H}\right]$ choline. 


\subsection{Analysis of Cellular Accumulation of Zinc and Cadmium}

Cells grown in 12-well plates were treated with $1 \mathrm{~mL}$ of experimental media. Total accumulation of elemental Zinc and elemental cadmium was determined by inductively coupled plasma-mass spectrometry (ICP-MS). The protocol for elemental metal analysis in cultured cells by ICP-MS is the standard analysis protocol used in the Trace Element Research Laboratory (College of Veterinary Medicine \& Biomedical Sciences, Texas A\&M University-College Station), which performed the analysis. This same protocol was used to determine cellular cadmium content in CPECs in our prior investigation of cadmiuminduced stress responses in CPECs [17]. Treated cells were rinsed twice with chilled PBS containing $1 \mathrm{mM}$ EDTA and once with chilled PBS (no EDTA). Within the original culture plate, cells were solubilized in $200 \mu \mathrm{L}$ concentrated nitric acid (Ultrex grade). The entire cell suspension was aspirated and transferred to a pre-weighed $15 \mathrm{~mL}$ tube $( \pm 0.1 \mathrm{mg})$; each well was rinsed with ultra-pure water several times, and each rinse was transferred to the $15 \mathrm{~mL}$ tube. Water was added to the tube to a final volume of $10 \mathrm{~mL}$ and final nitric acid concentration of $2 \%$, and the final weight was recorded $( \pm 0.1 \mathrm{mg})$. Samples were analyzed by ICP-MS (ELAN DRC-II inductive coupled plasma mass spectrometer, PerkinElmer Life and Analytical Sciences, Shelton, CT, USA) in the Trace Element Research Laboratory (College of Veterinary Medicine \& Biomedical Sciences, Texas A\&M University-College Station); mixed reference standards of Zinc and cadmium in $2 \% \mathrm{HNO}_{3}$ were analyzed to calibrate the instrument. Representative cells from the control and experimental groups were collected to determine protein content by Bradford assay with BSA standards (BioRad, Hercules, CA, USA). Total cellular accumulation of each element was expressed as nanograms per milligram protein and analyzed in duplicate in three separate culture preparations $(n=3)$.

\subsection{Intracellular Reduced Glutathione and Oxidized Glutathione Assay}

Total intracellular reduced glutathione (GSH) and oxidized glutathione (GSSG) concentrations were measured by the GSH/GSSG-Glo ${ }^{\mathrm{TM}}$ Assay (Promega, Madison, WI, USA), as per the protocol for adherent cells. CPECs were grown in flat-bottomed, white-walled 96-well plates (Corning, Suwanee, GA, USA). After treatment, cells were rinsed with HBSS and lysed in $50 \mu \mathrm{L}$ Total Glutathione Reagent or Oxidized Glutathione Reagent with vigorous rocking ( $5 \mathrm{~min}$; RT). Then, $50 \mu \mathrm{L}$ Luciferin Generation Reagent was added to each well, and the plate was incubated ( $30 \mathrm{~min}, \mathrm{RT}$ ). Finally, $100 \mu \mathrm{L}$ Luciferin Detection Reagent was added to each well, and the plate was incubated ( $45 \mathrm{~min}, \mathrm{RT}$ ) before determination of luminescence (Tecan Infinite M200 microplate reader, Morrisville, NC, USA). To quantify intracellular GSH and GSSG concentrations and calculate the ratio of GSH to GSSG (GSH:GSSG), relative light units (RLUs) of each sample were compared to RLUs determined for a set of GSH standards $(0,0.25,0.50,1,2,4,8$, and $16 \mu \mathrm{M})$. GSSG concentration was determined by extrapolated calculation based on the GSH standard curve.

\subsection{Analysis of Gene Expression}

Gene expression was analyzed by quantitative real-time polymerase chain reaction (qRT-PCR) with SYBR ${ }^{\circledR}$ Green detection, as described previously [17]. Total RNA was extracted from CPECs and isolated CP tissues with a RNeasy mini kit (Qiagen, Valencia, CA, USA). CPECs grown and treated in 12-well plates were rinsed with PBS and triturated in $500 \mu \mathrm{L}$ RLT lysis buffer $/ 1 \% \beta$-mercaptoethanol ( $\beta$-ME); CP tissues were rinsed with PBS and triturated in $600 \mu \mathrm{L}$ RLT $/ 1 \% \beta-\mathrm{ME}$. Cell and tissue lysates were homogenized by centrifugation through a QiaShredder. Homogenate was cleared with $70 \% \mathrm{EtOH}$ and loaded onto a RNeasy Spin column for DNase treatment (Qiagen, Valencia, CA, USA) and final elution of total RNA with RNase-free water. Each RNA sample was evaluated for quality and contamination per nanospectroscopic determination of Abs $260 \mathrm{~nm}$ :Abs $280 \mathrm{~nm}$ and Abs260 nm:Abs230 nm ratios (NanoDrop ${ }^{\circledR}$ ND-100, Thermo Scientific, Waltham, MA, USA) before preparation of first-strand cDNA (iScript cDNA Synthesis kit; Bio-Rad, Hercules, CA, USA). In each cDNA sample, each test gene was analyzed in triplicate in 
4-5 separate culture preparations by qRT-PCR with SYBR ${ }^{\circledR}$ Green detection (MyQ singlecolor real-time detection system, Bio-Rad, Hercules, CA, USA). Copy number for each gene was determined and normalized to integrated values for Actb ( $\beta$-actin) and Gapdh (GAPDH) mRNA expression; expression of these genes remained relatively stable and consistent under control and experimental conditions in our studies. Specifications for qRT-PCR analysis: initial denaturation $-10 \mathrm{~min}, 95^{\circ} \mathrm{C}$; amplification and quantification (45 cycles) $-15 \mathrm{~s}, 95^{\circ} \mathrm{C} ; 30 \mathrm{~s}, 60^{\circ} \mathrm{C}$; melt curve $-55^{\circ} \mathrm{C}-95^{\circ} \mathrm{C}$. Primers were designed by Primer Express software (PE Applied Biosystems, Foster City, CA, USA) based on GenBank sequences for rat genes Actb, Gapdh, Hspa4, Hmox1, Mt1, Gclc, and Gclm, synthesized by Integrated DNA Technologies (Coralville, IA, USA), and tested using cDNA from untreated cultured cells to ensure primer-primer dimerization did not occur. Forward and reverse primer sequences are listed in Table 5.

Table 5. Forward and reverse primer sequences used to analyze gene expression in rat choroid plexus epithelial cells and isolated rat choroid plexus tissues, listed by respective gene name.

\begin{tabular}{|c|c|c|c|}
\hline Gene & GeneBank ID & Forward Primer $\left(5-3^{\prime}\right)$ & Reverse Primer $\left(3^{\prime}-5^{\prime}\right)$ \\
\hline Actb & NM_031144 & ATGGTGGGTATGGGTCAG & TACTTCAGGGTCAGGATGC \\
\hline Gapdh & NM_017008 & ATGACTCTACCCACGGC & ACTCAGCACCAGCATCA \\
\hline Gclc & NM_012815 & GCTTTCTCСТACСТGTTTCTTG & TGGCAGAGTTCAGTTCCG \\
\hline Gclm & NM_017305 & TGTGATGCCACCAGATTTGA & TGGAAACTTGCCTCAGAGAG \\
\hline Hmox1 & NM_012580 & ACCCCACAAGTTCAAACAG & CCTCTGGCGAAGAACTCTG \\
\hline Hspa4 & NM_153629 & ATGGGGGACAAGTCGGA & GTGGGGATGGTGGAGTT \\
\hline Mt1 & NM_138826 & CACCGTTGCTCCAGATTCA & CAGCAGCACTGTTCGTCA \\
\hline
\end{tabular}

\subsection{Immunoblot Analysis}

Protein expression in CPECs grown and treated in 48-well or 96-well plates was determined by immunoblot analysis, as described previously [17]. Cells were solubilized in chilled lysis buffer with phosphatase and protease inhibitor cocktail, heat-denatured, sonicated, and centrifuged. Cellular proteins and molecular weight markers were electrophoresed (10\% SDS-PAGE) and electroblotted onto a polyvinylidene fluoride membrane by tank transfer. Membranes were blocked ( $1 \mathrm{~h}, \mathrm{RT})$ with $5 \%$ or $10 \%$ non-fat dry milk (NFDM) in TBS with $0.1 \%$ Tween 20 (TBS-T), then incubated in $5 \%$ or $10 \%$ NFDM/TBS-T with primary antibody $\left(2 \mathrm{~h}\right.$, RT or $\left.18 \mathrm{~h}, 4^{\circ} \mathrm{C}\right)$. Membranes were rinsed in TBS-T and incubated with goat-derived secondary antibody conjugated with alkaline-phosphatase (AP) or horseradish peroxidase (HRP; $90 \mathrm{~min}, \mathrm{RT}$ ). Immunoreactivity was detected by chromogenic staining with AP substrate 5-bromo-4-chloro-3-indolyl-phosphate/nitro blue tetrazolium (BCIP/NBT; Promega, Madison, WI, USA) or enhanced chemiluminescence with HRP substrate (Millipore, Bedford, MA, USA). Protein bands were analyzed by densitometry (Alpha Innotech FluoroChem HD2 gel documentation system, Santa Clara, CA, USA). Membranes were cleared of primary and secondary antibodies and probed for additional proteins. Primary antibodies against $\beta$-actin (Cat. No. A4700, Sigma-Aldrich, St. Louis, MO, USA), HO-1 (Cat. No. ADI-OSA-150, Enzo Life Sciences Farmingdale, NY, USA), and Hsp70 (Cat. No. ADI-SPA-812, Enzo Life Sciences, Farmingdale, NY, USA) were used at 1:1000 (10\% NFDM/TBS-T). Primary antibodies against GCLC (Cat. No. ab41463, Abcam, Cambridge, MA, USA) and GCLM (Cat. No. ab126704, Abcam, Cambridge, MA, USA) were used at 1:500 (5\% NFDM/TBS-T). AP-conjugated anti-mouse IgG secondary antibody (Cat. No. AP124A, Millipore-Sigma, Burlington, MA, USA) or HRP-conjugated anti-rabbit IgG secondary antibody (Cat. No. ADI-SAB-300, Enzo Life Sciences, Farmingdale, NY, USA) were used at 1:5000 in 10\% or 5\% NFDM/TBS-T. 


\subsection{Radiotracer Assay of Apical Choline Transport in CPECs}

Thirty-minute apical uptake of $\left[{ }^{3} \mathrm{H}\right]$ choline was assayed in cells plated in 48 -well tissue plates, as described previously [17]. After treatment, cells were rinsed with aCSF and incubated $\left(30 \mathrm{~min}, 37^{\circ} \mathrm{C}, 95 \%\right.$ air $/ 5 \% \mathrm{CO}_{2}$ ) with $200 \mu \mathrm{L}$ aCSF containing $10 \mu \mathrm{M}$ unlabeled choline chloride and trace $\left[{ }^{3} \mathrm{H}\right]$ choline chloride $\pm 750 \mu \mathrm{M}$ hemicholinium-3 (HC-3); the uptake buffer did not contain experimental agents; i.e., cadmium, Zinc, or BSO. Uptake was terminated by removal of buffer and a triple rinse with ice-cold isotope-free aCSF containing $5 \mathrm{mM}$ choline chloride; this also removed residual isotope from the culture well. Cells were solubilized in $200 \mu \mathrm{L} 1 \mathrm{M} \mathrm{NaOH}$ and neutralized with $200 \mu \mathrm{L} 1 \mathrm{~N} \mathrm{HCl}$. Two $50 \mu \mathrm{L}$ aliquots of solubilized cell suspension were collected to determine radioactivity by liquid scintillation (Beckman LC 6500 Scintillation Counter, Fullerton, CA, USA). One $50 \mu \mathrm{L}$ aliquot of cell suspension was collected to determine protein content (Bradford assay with BSA standard, Bio-Rad, Hercules, CA, USA). $\left[{ }^{3} \mathrm{H}\right]$ choline uptake was calculated as picomoles $\left[{ }^{3} \mathrm{H}\right]$ choline per milligram protein. Uptake was measured in triplicate (triplicate measures) in at least three separate culture preparations $(n=3)$. Data are reported as a percentage of mediated choline uptake by control cells; means $\pm \mathrm{SE}$. We had previously determined that in CPECs $24 \mathrm{~h}$ serum-deprivation does not alter $30 \mathrm{~min}$ apical uptake of $10 \mu \mathrm{M}\left[{ }^{3} \mathrm{H}\right]$ choline, as compared to that in cells incubated with 5\% NuSerum [17].

\subsection{Extracellular Lactate Dehydrogenase Assay}

Cytotoxicity was evaluated based on increased release of lactate dehydrogenase (LDH) from experimental versus control cells using the CytoTox $96{ }^{\circledR}$ Non-Radioactive Cytotoxicity Assay (Promega, Madison WI, USA). Cells grown in 48-well plates were incubated with $400 \mu \mathrm{L}$ treatment medium. Maximum LDH release was determined in non-treated control cells lysed with $0.9 \% v / v$ Triton X-100 $\left(45 \mathrm{~min}, 37^{\circ} \mathrm{C}\right)$. After treatment, three $50 \mu \mathrm{L}$ aliquots of treatment medium from each control and experimental well were transferred to individual wells of a 96-well plate. Substrate solution $(50 \mu \mathrm{L})$ was added to each sample; the mixture was incubated in the dark (10 min, RT). Stop solution (50 $\mu \mathrm{L})$ was added to each well, and Abs490 nm was recorded at $24{ }^{\circ} \mathrm{C}$ (Tecan Infinite M200 microplate reader, Morrisville, NC). Values were corrected for background absorbance; i.e., cell-free, serum-free DMEM/F12. LDH release was expressed as a percentage of maximal $\mathrm{LDH}$ release; $\mathrm{LDH}$ release was assayed in triplicate in three separate culture preparations (triplicate measures; $n=3$ ).

We assessed cytotoxicity of cadmium exposure and Zinc supplementation in presence of BSO by colorimetric assay of extracellular LDH release (Table 6). In control cells mean $\mathrm{LDH}$ release was $11 \%$ of maximal release. Cadmium insignificantly increased LDH release to $14 \%$. This was consistent with findings in our previous study [17]. Zinc did not alter LDH release, either alone or in cadmium-exposed cells. Similarly, BSO did not alter LDH release or alter release in cadmium-exposed cells. These data indicated treatment with these agents, individually or in combination, did not elicit marked cytotoxicity. 
Table 6. Lactate dehydrogenase (LDH) release in choroid plexus epithelial cells exposed for $12 \mathrm{~h}$ to $500 \mathrm{nM} \mathrm{CdCl}_{2}$ with Zinc supplementation and inhibition of glutathione synthesis by L-buthionine sulfoximine (BSO).

\begin{tabular}{|c|c|}
\hline Condition & $\begin{array}{c}\text { LDH Release } \\
\text { (\% Maximal Release) }\end{array}$ \\
\hline Control & $11.39 \pm 0.76$ \\
\hline $\mathrm{Cd}$ & $14.09 \pm 1.54$ \\
\hline $\mathrm{Zn}$ & $10.34 \pm 0.20$ \\
\hline $\mathrm{Zn}+\mathrm{Cd}$ & $10.49 \pm 0.22$ \\
\hline BSO & $10.89 \pm 0.34$ \\
\hline $\mathrm{BSO}+\mathrm{Cd}$ & $12.85 \pm 1.01$ \\
\hline $\mathrm{BSO}+\mathrm{Zn}$ & $10.55 \pm 0.85$ \\
\hline $\mathrm{BSO}+\mathrm{Zn}+\mathrm{Cd}$ & $10.61 \pm 0.29$ \\
\hline \multicolumn{2}{|c|}{ 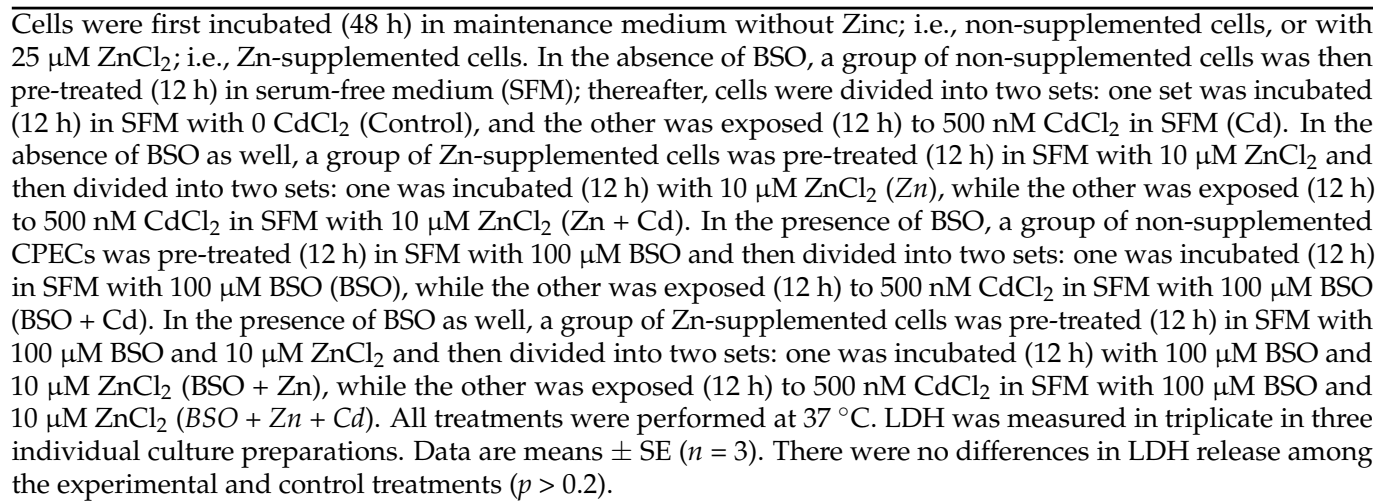 } \\
\hline
\end{tabular}

\subsection{Statistical Analysis}

Results are reported as means \pm SE of 3-5 experiments, each conducted in separate culture preparations or separate sets of isolated choroid plexus tissues. Statistical analyses were performed using JMP ${ }^{\circledR}$ statistical software by SAS (Cary, NC, USA). Control and experimental means were compared by one-way or two-way analysis of variance (ANOVA) or Student's t-test. Control and experimental means from experiments that evaluated effects of cadmium and Zinc treatments on metal accumulation, GSH chemistry, and apical choline uptake were compared by one-way ANOVA with a Tukey-Kramer post hoc test. Control and experimental means from experiments that evaluated time-dependent effects of cadmium on mRNA expression and protein expression in CPECs were compared by two-way ANOVA with a Tukey-Kramer post hoc test. If there was a significant group by time interaction, then group differences at each time point were compared using Student's $t$-test. Control and experimental means from experiments that evaluated concentrationdependent effects of Zinc on apical choline uptake were compared by one-way ANOVA with a Tukey-Kramer post hoc test. Control and experimental means from experiments that compared mRNA expression for each gene of interest in control and cadmium-treated isolated choroid plexus tissues were compared by a two-tailed Student's $t$-test. Similarly, control and experimental means from experiments that compared mRNA expression for each gene of interest in non-supplemented versus Zinc-supplemented cells that were not subjected to additional treatment with cadmium or BSO were compared by a two-tailed Student's $t$-test. Control and experimental means from experiments that investigated the effects of cadmium with manipulation of glutathione synthesis and Zinc supplementation were compared by one-way ANOVA with a Tukey-Kramer post hoc test. Differences were deemed significant at $p<0.05$.

\section{Conclusions}

In summary, a low-dose cadmium exposure sufficient to induce cellular stress stimulated choline uptake across the apical membrane of CPECs. Cells mounted an adaptive cellular stress response defined by a progressive induction of heme oxygenase protein 
and gene expression and metallothionein gene expression, along with biphasic induction of Hsp70 integrated with concurrent up-regulation of GSH synthesis. Supplementation with Zinc did not prevent onset of cellular stress elicited by cadmium, but facilitated adaptation and diminished stimulation of choline uptake independent of GSH. This study lends insight into how neonatal and possibly adult CP epithelium may sequester contaminant heavy metals, but not succumb to cellular injury and modulation by the very agents from which it protects the brain. Our data indicated that Zinc did not impair the capacity of CPECs to accumulate cadmium. Thus, Zinc is not only protective of choroid plexus biology, but could potentially protect this epithelium, as it still sequesters toxic metals and continues to protect the brain from their neurotoxic effects. These data also suggest an animal's Zinc status and capacity of CP epithelium to accumulate Zinc may dictate the efficacy of cytoprotective mechanisms that minimize cellular injury and dysfunction elicited by cellular stress.

Author Contributions: Conceptualization, A.R.V. and S.D.F.S.; methodology, A.R.V. and S.D.F.S.; validation, A.R.V. and S.D.F.S.; formal analysis, A.R.V. and S.D.F.S.; investigation, A.R.V. and S.D.F.S.; resources, A.R.V.; data curation, A.R.V.; writing—original draft preparation, A.R.V. and S.D.F.S.; writing - review and editing, A.R.V. and S.D.F.S.; supervision, A.R.V.; project administration, A.R.V.; funding acquisition, A.R.V. All authors have read and agreed to the published version of the manuscript.

Funding: This work was supported by a research award to A.R.V. from the National Science Foundation (IOS 1052654).

Institutional Review Board Statement: Not applicable.

Informed Consent Statement: Not applicable.

Data Availability Statement: The data presented in this study are available upon request from the corresponding author.

Acknowledgments: This work was conducted in partial fulfillment of the degree of Master of Science at Texas A\&M University in the subject of toxicology by S.D.F.S. The authors thank Robin Young for her assistance with preparation of the primary choroid plexus cultures and Robert J. Taylor for assistance with the elemental analysis of Zinc and cadmium.

Conflicts of Interest: The authors declare no conflict of interest. The funders had no role in the design of this study, in the collection, analyses or interpretation of data, in the writing of the manuscript; or in the decision to publish the results.

\section{References}

1. Abbott, N.J. Dynamics of CNS barriers: Evolution, differentiation, and modulation. Cell. Mol. Neurobiol. 2005, 25, 5-23. [CrossRef]

2. Praetorius, J.; Damkier, H.H. Transport across the choroid plexus epithelium. Am. J. Physiol.-Cell Physiol. 2017, 312, C673-C686. [CrossRef]

3. Redzic, Z.B.; Preston, J.E.; Duncan, J.A.; Chodobski, A.; Szmydynger-Chodobska, J. The choroid plexus-cerebrospinal fluid system: From development to aging. Curr. Top. Dev. Biol. 2005, 71, 1-52. [CrossRef]

4. Strazielle, N.; Ghersi-Egea, J.F. Physiology of blood-brain interfaces in relation to brain disposition of small compounds and macromolecules. Mol. Pharm. 2013, 10, 1473-1491. [CrossRef] [PubMed]

5. Friedheim, E.; Corvi, C.; Graziano, J.; Donnelli, T.; Breslin, D. Choroid plexus as a protective sink for heavy metals? Lancet 1983, 1, 981-982. [CrossRef]

6. Zheng, W. Toxicology of choroid plexus: Special reference to metal-induced neurotoxicities. Microsc. Res. Tech. 2001, 52, 89-103. [CrossRef]

7. Zheng, W.; Perry, D.F.; Nelson, D.L.; Aposhian, H.V. Choroid plexus protects cerebrospinal fluid against toxic metals. FASEB J. 1991, 5, 2188-2193. [CrossRef] [PubMed]

8. Arvidson, B.; Tjälve, H. Distribution of ${ }^{109} \mathrm{Cd}$ in the nervous system of rats after intravenous injection. Acta Neuropathol. 1986, 69, 111-116. [CrossRef] [PubMed]

9. Takeda, A.; Takefuta, S.; Ijiro, H.; Okada, S.; Oku, N. ${ }^{109}$ Cd transport in rat brain. Brain Res. Bull. 1999, 49, 453-457. [CrossRef]

10. Valois, A.A.; Webster, W.S. The choroid plexus as a target site for cadmium toxicity following chronic exposure in the adult mouse: An ultrastructural study. Toxicology 1989, 55, 193-205. [CrossRef]

11. Agency for Toxic Substances and Disease Registry. Toxicological Profile for Cadmium; Department of Health and Human Services, Public Health Service: Atlanta, GA, USA, 2012. 
12. Satarug, S.; Garrett, S.H.; Sens, M.A.; Sens, D.A. Cadmium, environmental exposure, and health outcomes. Environ. Health Perspect. 2010, 118, 182-190. [CrossRef]

13. Jomova, K.; Valko, M. Advances in metal-induced oxidative stress and human disease. Toxicology 2011, 283, 65-87. [CrossRef]

14. Casalino, E.; Sblano, C.; Landriscina, C. Enzyme activity alteration by cadmium administration to rats: The possibility of iron involvement in lipid peroxidation. Arch. Biochem. Biophys. 1997, 346, 171-179. [CrossRef] [PubMed]

15. L'hoste, S.; Chargui, A.; Belfodil, R.; Duranton, C.; Rubera, I.; Mograbi, B.; Poujeol, C.; Tauc, M.; Poujeol, P. CFTR mediates cadmium-induced apoptosis through modulation of ROS level in mouse proximal tubule cells. Free Radic. Biol. Med. 2009, 46, 1017-1031. [CrossRef] [PubMed]

16. Wang, Y.; Fang, J.; Leonard, S.S.; Rao, K.M. Cadmium inhibits the electron transfer chain and induces reactive oxygen species. Free Radic. Biol. Med. 2004, 36, 1434-1443. [CrossRef] [PubMed]

17. Young, R.K.; Villalobos, A.R. Stress-induced stimulation of choline transport in cultured choroid plexus epithelium exposed to low concentrations of cadmium. Am. J. Physiol. Regul. Integr. Comp. Physiol. 2014, 306, R291-R303. [CrossRef]

18. Sweet, D.H.; Miller, D.S.; Pritchard, J.B. Ventricular choline transport: A role for organic cation transporter 2 expressed in choroid plexus. J. Biol. Chem. 2001, 276, 41611-41619. [CrossRef] [PubMed]

19. Zeisel, S.H. Choline: Essential for brain development and function. Adv. Pediatrics 1997, 44, 263-295. [CrossRef]

20. Zeisel, S.H. Nutritional importance of choline for brain development. J. Am. Coll. Nutr. 2004, 23, 621S-626S. [CrossRef]

21. Derbyshire, E.; Obeid, R. Choline, Neurological development and brain function: A systematic review focusing on the first 1000 days. Nutrients 2020, 12, 1731. [CrossRef]

22. Lu, S.C. Glutathione synthesis. Biochim. Biophys. Acta 2013, 1830, 3143-3153. [CrossRef]

23. Singhal, R.K.; Anderson, M.E.; Meister, A. Glutathione, a first line of defense against cadmium toxicity. FASEB J. 1987, 1, $220-223$. [CrossRef]

24. Suzuki, C.A.; Cherian, M.G. Renal glutathione depletion and nephrotoxicity of cadmium-metallothionein in rats. Toxicol. Appl. Pharmacol. 1989, 98, 544-552. [CrossRef]

25. Cuypers, A.; Plusquin, M.; Remans, T.; Jozefczak, M.; Keunen, E.; Gielen, H.; Opdenakker, K.; Nair, A.R.; Munters, E.; Artois, T.J.; et al. Cadmium stress: An oxidative challenge. Biometals 2010, 23, 27-40. [CrossRef]

26. Tate, S.S.; Ross, L.L.; Meister, A. The g-glutamyl cycle in the choroid plexus: Its possible function in amino acid transport. Proc. Natl. Acad. Sci. USA 1973, 70, 1447-1449. [CrossRef] [PubMed]

27. Ghersi-Egea, J.F.; Strazielle, N.; Murat, A.; Jouvet, A.; Buénerd, A.; Belin, M.F. Brain protection at the blood-cerebrospinal fluid interface involves a glutathione-dependent metabolic barrier mechanism. J. Cereb. Blood Flow Metab. 2006, 26, 1165-1175. [CrossRef] [PubMed]

28. Saudrais, E.; Strazielle, N.; Ghersi-Egea, J.F. Choroid plexus glutathione peroxidases are instrumental in protecting the brain fluid environment from hydroperoxides during postnatal development. Am. J. Physiol.-Cell Physiol. 2018, 315, C445-C456. [CrossRef] [PubMed]

29. Kasarskis, E.J. Zinc metabolism in normal and Zinc-deficient rat brain. Exp. Neurol. 1984, 85, 114-127. [CrossRef]

30. Nitzan, Y.B.; Sekler, I.; Silverman, W.F. Histochemical and histofluorescence tracing of chelatable Zinc in the developing mouse. J. Histochem. Cytochem. 2004, 52, 529-539. [CrossRef]

31. Wang, Z.Y.; Stoltenberg, M.; Jo, S.M.; Huang, L.; Larsen, A.; Dahlström, A.; Danscher, G. Dynamic Zinc pools in mouse choroid plexus. Neuroreport 2004, 15, 1801-1804. [CrossRef]

32. Damkier, H.H.; Brown, P.D.; Praetorius, J. Cerebrospinal fluid secretion by the choroid plexus. Physiol. Rev. 2013, 93, 1847-1892. [CrossRef]

33. Vallee, B.L.; Falchuk, K.H. The biochemical basis of Zinc physiology. Physiol. Rev. 1993, 73, 79-118. [CrossRef]

34. Oteiza, P.I. Zinc and the modulation of redox homeostasis. Free Radic. Biol. Med. 2012, 53, 1748-1759. [CrossRef]

35. Nzengue, Y.; Candéias, S.M.; Sauvaigo, S.; Douki, T.; Favier, A.; Rachidi, W.; Guiraud, P. The toxicity redox mechanisms of cadmium alone or together with copper and Zinc homeostasis alteration: Its redox biomarkers. J. Trace Elem. Med. Biol. 2011, 25, 171-180. [CrossRef] [PubMed]

36. Kojima-Yuasa, A.; Ohkita, T.; Yukami, K.; Ichikawa, H.; Takami, N.; Nakatani, T.; Opare Kennedy, D.; Nishiguchi, S.; Matsui-Yuasa, I. Involvement of intracellular glutathione in Zinc deficiency-induced activation of hepatic stellate cells. Chem. Biol. Interact. 2003, 146, 89-99. [CrossRef]

37. Omata, Y.; Salvador, G.A.; Supasai, S.; Keenan, A.H.; Oteiza, P.I. Decreased Zinc availability affects glutathione metabolism in neuronal cells and in the developing brain. Toxicol. Sci. 2013, 133, 90-100. [CrossRef]

38. Bernotiene, R.; Ivanoviene, L.; Sadauskiene, I.; Liekis, A.; Ivanov, L. The effects of cadmium chloride and sodium selenite on protein synthesis in mouse liver. Environ. Toxicol. Pharmacol. 2013, 36, 1261-1265. [CrossRef] [PubMed]

39. Maret, W. Redox biochemistry of mammalian metallothioneins. J. Biol. Inorg. Chem. 2011, 16, 1079-1086. [CrossRef] [PubMed]

40. Tang, W.; Sadovic, S.; Shaikh, Z.A. Nephrotoxicity of cadmium-metallothionein: Protection by Zinc and role of glutathione. Toxicol. Appl. Pharmacol. 1998, 151, 276-282. [CrossRef]

41. Wessells, K.R.; Brown, K.H. Estimating the global prevalence of Zinc deficiency: Results based on Zinc availability in national food supplies and the prevalence of stunting. PLoS ONE 2012, 7, e50568. [CrossRef]

42. Wessells, K.R.; Singh, G.M.; Brown, K.H. Estimating the global prevalence of inadequate Zinc intake from national food balance sheets: Effects of methodological assumptions. PLoS ONE 2012, 7, e50565. [CrossRef] 
43. Franklin, C.C.; Backos, D.S.; Mohar, I.; White, C.C.; Forman, H.J.; Kavanagh, T.J. Structure, function, and post-translational regulation of the catalytic and modifier subunits of glutamate cysteine ligase. Mol. Asp. Med. 2009, 30, 86-98. [CrossRef]

44. Anderson, M.E.; Underwood, M.; Bridges, R.J.; Meister, A.M. Glutathione metabolism at the blood-cerebrospinal fluid barrier. FASEB J. 1989, 3, 2527-2531. [CrossRef]

45. Zhang, J.; Zhou, X.; Wu, W.; Wang, J.; Xie, H.; Wu, Z. Regeneration of glutathione by $\alpha$-lipoic acid via Nrf2/ARE signaling pathway alleviates cadmium-induced HepG2 cell toxicity. Environ. Toxicol. Pharmacol. 2017, 51, 30-37. [CrossRef] [PubMed]

46. Chin, T.A.; Templeton, D.M. Protective elevations of glutathione and metallothionein in cadmium-exposed mesangial cells. Toxicology 1993, 77, 145-156. [CrossRef]

47. Sauvageau, J.A.; Jumarie, C. Different mechanisms for metal-induced adaptation to cadmium in the human lung cell lines A549 and H441. Cell Biol. Toxicol. 2013, 29, 159-173. [CrossRef] [PubMed]

48. Solis, W.A.; Dalton, T.P.; Dieter, M.Z.; Freshwater, S.; Harrer, J.M.; He, L.; Shertzer, H.G.; Nebert, D.W. Glutamate-cysteine ligase modifier subunit: Mouse Gclm gene structure and regulation by agents that cause oxidative stress. Biochem. Pharmacol. 2002, 63, 1739-1754. [CrossRef]

49. Djukić-Cosić, D.; Ninković, M.; Malicević, Z.; Matović, V.; Soldatović, D. Effect of magnesium pretreatment on reduced glutathione levels in tissues of mice exposed to acute and subacute cadmium intoxication: A time course study. Magnes Res. 2007, 20, 177-186. [CrossRef]

50. Hahn, H.; Huck, C.W.; Rainer, M.; Najam-ul-Haq, M.; Bakry, R.; Abberger, T.; Jennings, P.; Pfaller, W.; Bonn, G.K. Analysis of glutathione in supernatants and lysates of a human proximal tubular cell line from perfusion culture upon intoxication with cadmium chloride by HPLC and LC-ESI-MS. Anal. Bioanal. Chem. 2007, 388, 1763-1769. [CrossRef]

51. Li, W.; Zhao, Y.; Chou, I.N. Alterations in cytoskeletal protein sulfhydryls and cellular glutathione in cultured cells exposed to cadmium and nickel ions. Toxicology 1993, 77, 65-79. [CrossRef] [PubMed]

52. Shukla, G.S.; Shukla, A.; Potts, R.J.; Osier, M.; Hart, B.A.; Chiu, J.F. Cadmium-mediated oxidative stress in alveolar epithelial cells induces the expression of gamma-glutamylcysteine synthetase catalytic subunit and glutathione S-transferase alpha and pi isoforms: Potential role of activator protein-1. Cell Biol. Toxicol. 2000, 16, 347-362. [CrossRef]

53. McConnachie, L.A.; Botta, D.; White, C.C.; Weldy, C.S.; Wilkerson, H.W.; Yu, J.; Dills, R.; Yu, X.; Griffith, W.C.; Faustman, E.M.; et al. The glutathione synthesis gene Gclm modulates amphiphilic polymer-coated CdSe/ZnS quantum dot-induced lung inflammation in mice. PLoS ONE 2013, 8, e64165. [CrossRef]

54. Koizumi, S.; Gong, P.; Suzuki, K.; Murata, M. Cadmium-responsive element of the human heme oxygenase-1 gene mediates heat shock factor 1-dependent transcriptional activation. J. Biol. Chem. 2007, 282, 8715-8723. [CrossRef] [PubMed]

55. Chan, H.M.; Cherian, M.G. Protective roles of metallothionein and glutathione in hepatotoxicity of cadmium. Toxicology 1992, 72, 281-290. [CrossRef]

56. Dahlgaard, J.; Loeschcke, V.; Michalak, P.; Justesen, J. Induced thermotolerance and associated expression of heat-shock protein Hsp70 in adult Drosophila melanogaster. Funct. Ecol. 1998, 12, 786-793. [CrossRef]

57. DiDomenico, B.J.; Bugaisky, G.E.; Lindquist, S. The heat shock response is self-regulated at both the transcriptional and posttranscriptional levels. Cell 1982, 31, 593-603. [CrossRef]

58. Waalkes, M.P.; Perantoni, A. In vitro assessment of target cell specificity in cadmium carcinogenesis: Interactions of cadmium and Zinc with isolated interstitial cells of the rat testes. In Vitro Cell. Dev. Biol. 1988, 24, 558-565. [CrossRef]

59. Napolitano, J.R.; Liu, M.J.; Bao, S.; Crawford, M.; Nana-Sinkam, P.; Cormet-Boyaka, E.; Knoell, D.L. Cadmium-mediated toxicity of lung epithelia is enhanced through NF-kB-mediated transcriptional activation of the human Zinc transporter ZIP8. Am. J. Physiol. Lung Cell. Mol. Physiol. 2012, 302, L909-L918. [CrossRef] [PubMed]

60. Suzuki, H.; Tashiro, S.; Sun, J.; Doi, H.; Satomi, S.; Igarashi, K. Cadmium induces nuclear export of Bach1, a transcriptional repressor of heme oxygenase-1 gene. J. Biol. Chem. 2003, 278, 49246-49253. [CrossRef]

61. Brown, M.A.; Upender, R.P.; Hightower, L.E.; Renfro, J.L. Thermoprotection of a functional epithelium: Heat stress effects on transepithelial transport by flounder renal tubule in primary monolayer culture. Proc. Natl. Acad. Sci. USA 1992, 89, 3246-3250. [CrossRef] [PubMed]

62. Renfro, J.L.; Brown, M.A.; Parker, S.L.; Hightower, L.E. Relationship of thermal and chemical tolerance to transepithelial transport by cultured flounder renal epithelium. J. Pharmacol. Exp. Ther. 1993, 265, 992-1000.

63. Sussman, C.R.; Renfro, J.L. Heat shock-induced protection and enhancement of $\mathrm{Na}^{+}$-glucose cotransport by LLC-PK1 monolayers. Am. J. Physiol. 1997, 273, F530-F5307. [CrossRef]

64. Liu, J.; Squibb, K.S.; Akkerman, M.; Nordberg, G.F.; Lipsky, M.; Fowler, B.A. Cytotoxicity, Zinc protection, and stress protein induction in rat proximal tubule cells exposed to cadmium chloride in primary cell culture. Ren. Fail. 1996, 18, 867-882. [CrossRef] [PubMed]

65. Villalobos, A.R.; Renfro, J.L. Trimethylamine oxide suppresses stress-induced alteration of organic anion transport in choroid plexus. J. Exp. Biol. 2007, 210, 541-552. [CrossRef] [PubMed]

66. Jihen, E.H.; Sonia, S.; Fatima, H.; Mohamed Tahar, S.; Abdelhamid, K. Interrelationships between cadmium, Zinc and antioxidants in the liver of the rat exposed orally to relatively high doses of cadmium and Zinc. Ecotoxicol. Environ. Saf. 2011, 74, $2099-2104$. [CrossRef] [PubMed]

67. Rezaei, K.A.; Chen, Y.; Cai, J.; Sternberg, P. Modulation of Nrf2-dependent antioxidant functions in the RPE by Zip2, a Zinc transporter protein. Investig. Ophthalmol. Vis. Sci. 2008, 49, 1665-1670. [CrossRef] [PubMed] 
68. Min, K.S.; Tanaka, N.; Horie, T.; Kawano, H.; Tetsuchikawahara, N.; Onosaka, S. Metallothionein-enriched hepatocytes are resistant to ferric nitriloacetate toxicity during conditions of glutathione depletion. Toxicol. Lett. 2005, 158, 108-115. [CrossRef]

69. Chimienti, F.; Jourdan, E.; Favier, A.; Seve, M. Zinc resistance impairs sensitivity to oxidative stress in HeLa cells: Protection through metallothioneins expression. Free Radic. Biol. Med. 2001, 31, 1179-1190. [CrossRef]

70. Saito, C.; Yan, H.M.; Artigues, A.; Villar, M.T.; Farhood, A.; Jaeschke, H. Mechanism of protection by metallothionein against acetaminophen hepatotoxicity. Toxicol. Appl. Pharmacol. 2010, 242, 182-190. [CrossRef]

71. Lichten, L.A.; Cousins, R.J. Mammalian Zinc transporters: Nutritional and physiologic regulation. Annu. Rev. Nutr. 2009, 29, 153-176. [CrossRef]

72. Thornalley, P.J.; Vasák, M. Possible role for metallothionein in protection against radiation-induced oxidative stress. Kinetics and mechanism of its reaction with superoxide and hydroxyl radicals. Biochim. Biophys. Acta 1985, 827, 36-44. [CrossRef]

73. Villalobos, A.R.; Parmelee, J.T.; Renfro, J.L. Choline uptake across the ventricular membrane of neonate rat choroid plexus. Am. J. Physiol. 1999, 276, C1288-C1296. [CrossRef] [PubMed]

74. Villalobos, A.R.; Parmelee, J.T.; Pritchard, J.B. Functional characterization of choroid plexus epithelial cells in primary culture. J. Pharmacol. Exp. Ther. 1997, 282, 1109-1116. [PubMed]

75. Lazzaro, V.A.; Walker, R.J.; Duggin, G.G.; Phippard, A.; Horvath, J.S.; Tiller, D.J. Inhibition of fibroblast proliferation in L-valine reduced selective media. Res. Commun. Chem. Pathol. Pharmacol. 1992, 7, 39-48.

76. Suthanthiran, M.; Anderson, M.E.; Sharma, V.K.; Meister, A. Glutathione regulates activation-dependent DNA synthesis in highly purified normal human T lymphocytes stimulated via the CD2 and CD3 antigens. Proc. Natl. Acad. Sci. USA 1990, 87, 3343-3347. [CrossRef] [PubMed] 